\title{
On the descent of the epididymo-testicular unit, cryptorchidism, and prevention of infertility
}

Faruk Hadziselimovic ${ }^{1,2}$

\begin{abstract}
This comprehensive review provides in-depth coverage of progress made in understanding the molecular mechanisms underlying cryptorchidism, a frequent pathology first described in about 1786 by John Hunter. The first part focuses on the physiology, embryology, and histology of epididymo-testicular descent. In the last 20 years epididymo-testicular descent has become the victim of schematic drawings with an unjustified rejection of valid histological data. This part also includes discussion on the roles of gonadotropin-releasing hormone, fibroblast growth factors, Müllerian inhibiting substance, androgens, inhibin B, and insulin-like 3 in epididymo-testicular descent. The second part addresses the etiology and histology of cryptorchidism as well as the importance of minipuberty for normal fertility development. A critical view is presented on current clinical guidelines that recommend early orchidopexy alone as the best possible treatment. Finally, by combining classical physiological information and the output of cutting-edge genomics data into a complete picture the importance of hormonal treatment in preventing cryptorchidism-induced infertility is underscored.
\end{abstract}

Keywords: Epididymo-testicular descent, Cryptorchidism, RNA sequencing, GnRHa-treatment, Mini-puberty, Infertility

\section{Résumé}

Cette revue complète traite en profondeur les progrès réalisés dans la compréhension des mécanismes moléculaires à la base de la cryptorchidie, une pathologie fréquente décrite pour la première fois aux environs de 1786 par John Hunter. La première partie est. centrée sur la physiologie, l'embryologie et l'histologie de la descente épididymo-testiculaire. Durant les 20 dernières années, la descente épididymo-testiculaire est. devenue la victime de dessins schématiques associés à un rejet injustifié de données histologiques valides. Cette partie discute aussi les rôles qu'ont dans la descente épididymo-testiculaire l'hormone libérant les gonadotrophines, les facteurs de croissance fibroblastiques, l'hormone antimüllérienne, les androgènes, l'inhibine B, et l'insuline-like 3. La seconde partie aborde l'étiologie et l'histologie, ainsi que l'importance de la minipuberté pour un développement normal de la fertilité. Un regard critique est. porté sur les recommandations cliniques actuelles qui conseillent la seule orchidopexie précoce comme le meilleur traitement possible. Finalement, en combinant les informations issues de la physiologie classique et la production des données génomiques les plus en pointe dans (Continued on next page)

\footnotetext{
Correspondence: liestal@kindermedizin-zentrum.ch

${ }^{1}$ Cryptorchidism Research Institute, Kindermedizinisches Zentrum Liestal, Liestal, Switzerland

${ }^{2}$ Pediatrics at the University of Basel and Director of Cryptorchidism Research Institfigute, Kindermedizinisches Zentrum, Bahnhofplatz 11, 4410 Liestal, Switzerland
} 
(Continued from previous page)

un tableau complet, l'importance du traitement hormonal dans la prévention de l'infertilité induite par la cryptorchidie est soulignée.

Mots-clés: Descente épididymo-testiculaire, Cryptorchidie, Séquençage d'ARN, Analogue du Gn-RH, Minipuberté, Infertilité

\section{Epididymo-testicular descent}

Several animal studies have shown that the testis regulates its own descent by secreting hormones [for a summary see [1]. Furthermore, it is generally believed that hormonal stimulation induces a gubernacular reaction that is thought to be the most important mechanism for successful descent of the male gonad [1-4]. That said, complete early neonatal transection of the gubernaculum does not prevent epididymo-testicular descent [5] calling its postulated role into question.

Rather than gubernaculum elongation and differentiation, it is actually the developing epididymis that enlarges and holds the testis towards the developing scrotum during the process of descent (Figs. 1, 2, 3, 4, 5, 6, 7, 8, 9 and 10). Histological sections clearly show that the epididymis precedes the testis throughout the entire descent (Figs. 1, 2, 3, 4, 5, 6, 7, 8, 9 and 10). Furthermore, no migration of the gelatinous gubernaculum as presented in a schematic drawing by Hutson is visible in a series of sagittal histological sections [4] (Figs. 4, 5, 6, 7, 8, 9 and 10). In contrast, carried by the epididymis, each testis descends from the dorsal abdominal wall into the scrotum, together with a gelatinous gubernacular mass, that dilates the inguinal canal and thus creates space for the descent of the epididymo-testicular unit [6]. In a graphic drawn synopsis of testicular descent, Barteczko and Jakob connected the gubernaculum to the caudal testicular pole during the entire descent [3] (Fig. 11). This depiction however, is not confirmed by precise histological examination and therefore needs to be corrected accordingly (Figs. 1, 2, 3, 4, 5, 6, 7, 8, 9, 10 and 11). The gubernaculum is attached proximally either to the Wolffian duct or to the caudal pole of the epididymis, but never to the testis (Figs. 1, 2, 3, 4, 5, 6, 7, 8, 9 and 10).

Evidence so far suggests that Wolffian duct elongation occurs primarily through a combination of cell proliferation and cell rearrangements [7]. In rodents Wolffian duct coiling moves from proximal to distal in a temporal fashion and the initial stages are planar (i.e., the coiling occurs at the two-dimensional level) [7]. It has been hypothesized that the reason for the length of the duct is that without it sperm maturation would not have enough time to occur [7]. In turn, coiling of the Wolffian duct into a $6 \mathrm{~m}$ long ductus epididymis that is then packed into a $5-\mathrm{cm}$ long epididymal sheet starting from the proximal towards the distal produces forces that are important for epididymo-testicular descent [8]. Thus, disturbances of epididymal development results in a cryptorchid position of the epididymo-testicular unit $[6,9,10]$.

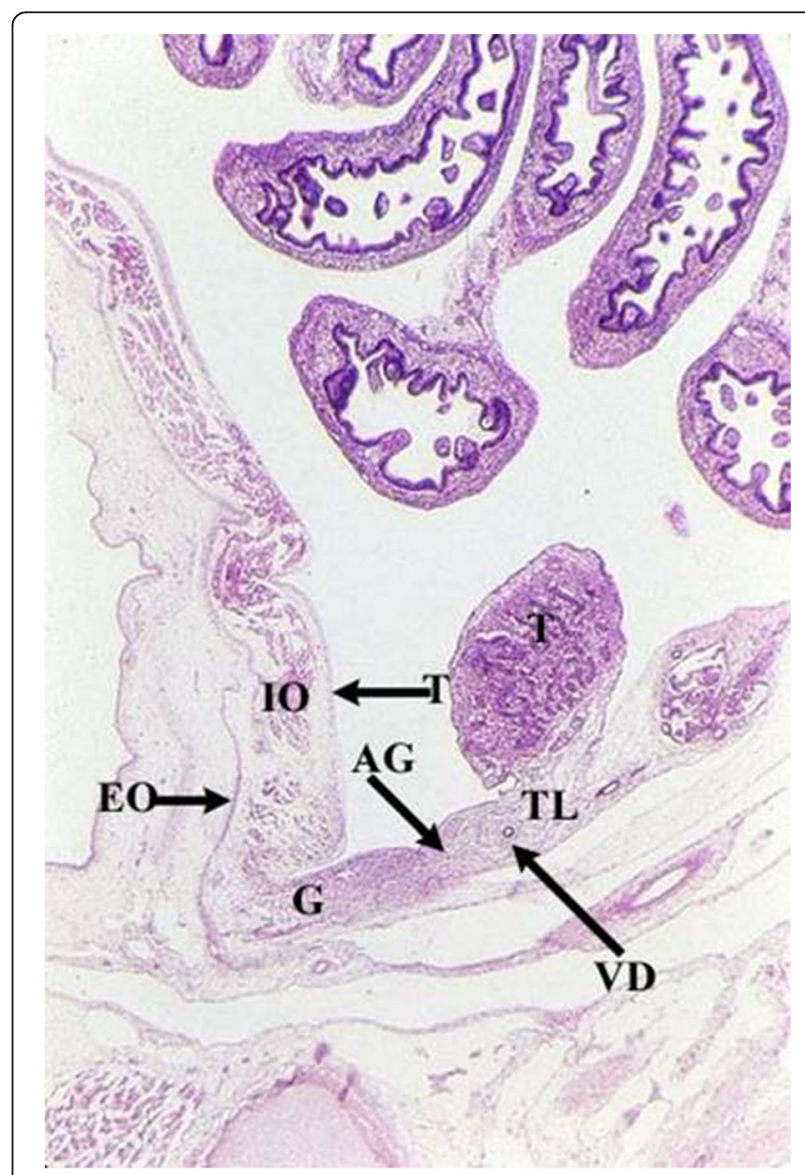

Fig. 1 10-week-old male fetus with testis (T) located intra-abdominally and intraperitoneally. Testis is connected to Wolffian duct (VD) with the testicular ligament (TL) while the gubernaculum, which is divided into two parts, inserts proximally into the Wolffian duct via an intraabdominal part ( $A G$ ) and an inguinal part (G). Internal abdominal oblique muscle $(\mathrm{IO})$ and fascia of extra-abdominal oblique muscle (EO and arrow) as well as fascia from transversal abdominal muscle ( $T$ and arrow) are labeled 


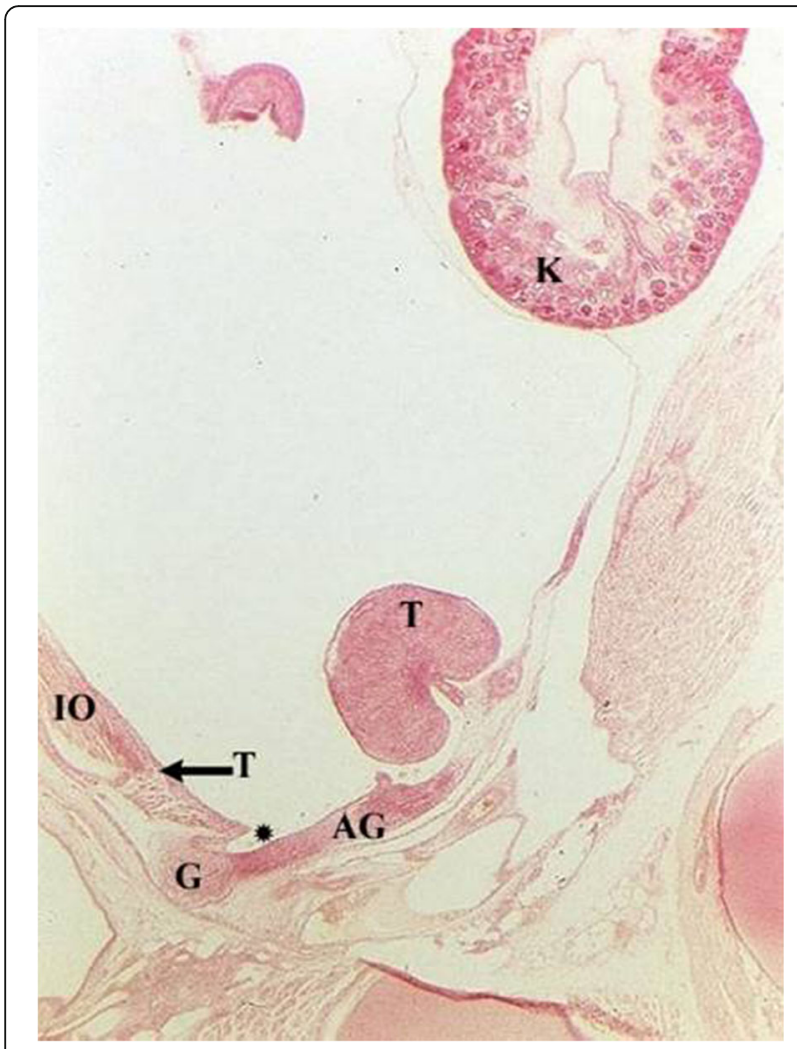

Fig. 2 Four-month-old fetus with intra-abdominal and intraperitoneal testis $(T)$ with meso-testis at the dorsal abdominal wall below the kidney $(\mathrm{K})$. Processus vaginalis starts to develop $\left(^{*}\right)$. The topographical relation of gubernaculum and developing Wolffian duct is identical as in Fig. 1. However, in parallel to the new formation of processus vaginalis the inguinal part of the gubernaculum also enlarges

The roles of gonadotropin-releasing hormone $(\mathrm{GnRH})$ and fibroblast growth factors (FGFs)

GnRH neurons are essential for epididymo-testicular descent and the onset and maintenance of sexual reproduction. Proper specification of $\mathrm{GnRH}$ cell fate, both prenatally and postnatally, relies on FGFs [11], and the developing GnRH system is highly sensitive to reduced levels of FGF signaling [12]. FGF-mediated signaling is involved in mitogenesis, proliferation, differentiation, cellular migration, angiogenesis, and tissue injury repair [13]. FGFR1 hypomorphy severely reduces the total number of $\mathrm{GnRH}$ neurons, inducing congenital hypogonadotropic hypogonadism, either alone or in association with other hypothalamic-pituitary deficiencies [12]. Severe hypoplastic crypto-epididymis has been observed in transgenic mice with migratory arrest of GnRH neurons [14], as well as in hypogonadal mice lacking $\mathrm{GnRH}$ [15], and in mice with loss-of-function mutations in the $G n R H$ receptor gene [16], which underlines the importance of $\mathrm{GnRH}$ in this developmental process. Hypogonadal male mice lacking $G n R H$ are cryptorchid but have a normal gubernaculum, and

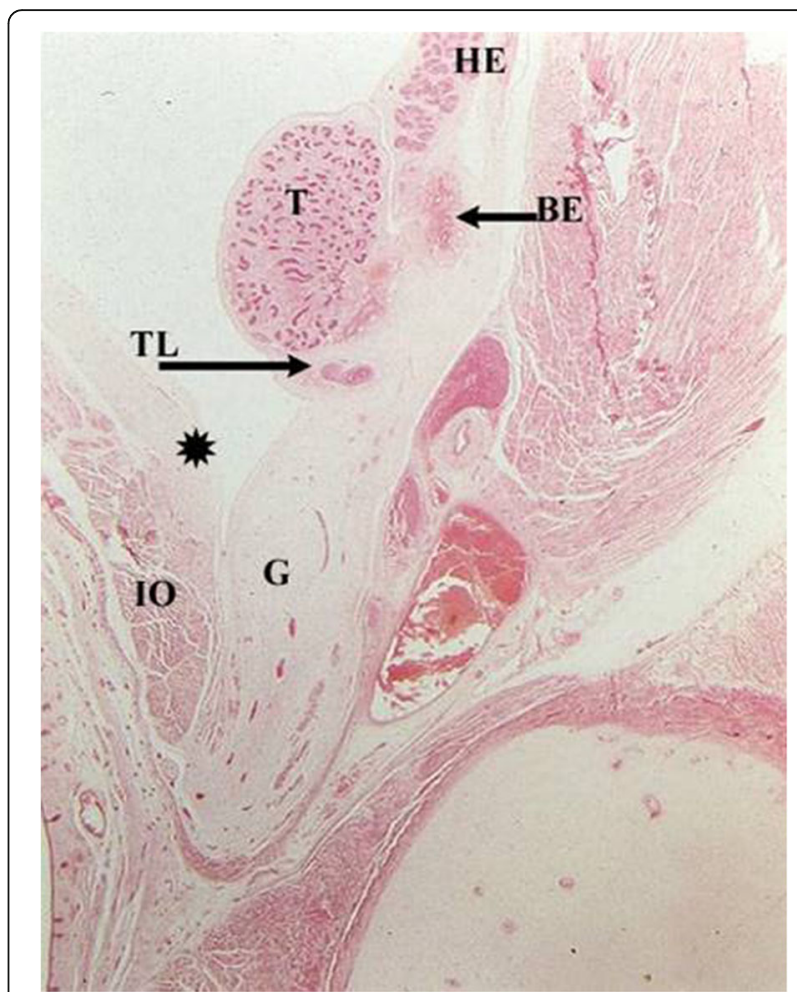

Fig. 3 Sagittal cut through epididymo-testicular unit of a fivemonth-old fetus. Testis ( $\mathrm{T}$ ) is surrounded by head (HE), body (BE) and tail (TL) of the epididymis. The testicular ligament, the connection between testis and the tail of the epididymis (TL) becomes narrow. The inguinal parts of gelatinous gubernaculum $(G)$ show cremaster muscle fibers at its periphery. Processus vaginalis $\left(^{*}\right)$ and internal oblique muscle $(I O)$ are indicated

gonadotropin treatment leads to normal testes development and descent [15].

In cryptorchid boys, GnRH treatment reportedly induces increased testosterone secretion and stimulates further epididymis development and completion of epididymo-testicular descent [17]. Boys with successful descent of the epididymis and testis have a normal-sized epididymis, while the majority of non-responders to hormonal treatment have a small and underdeveloped epididymis [17]. Of interest, luteinizing hormone (LH) receptor knockout mice exhibit bilateral cryptorchidism that can be corrected by testosterone replacement therapy [18]. Specifically, this therapy reverses all of the morphological and gene expression changes in the knockout mice, except those related to insulin-like factor3 (Insl3), suggesting that testosterone rather than INSL3 facilitates completion of testicular descent [18]. Furthermore, in $66 \%$ of naturally cryptorchid mice, treatment with LH-RH hormone reportedly induces epididymo-testicular descent, while increasing testosterone secretion and normalizing the morphology of an underdeveloped cryptorchid epididymis [19]. 


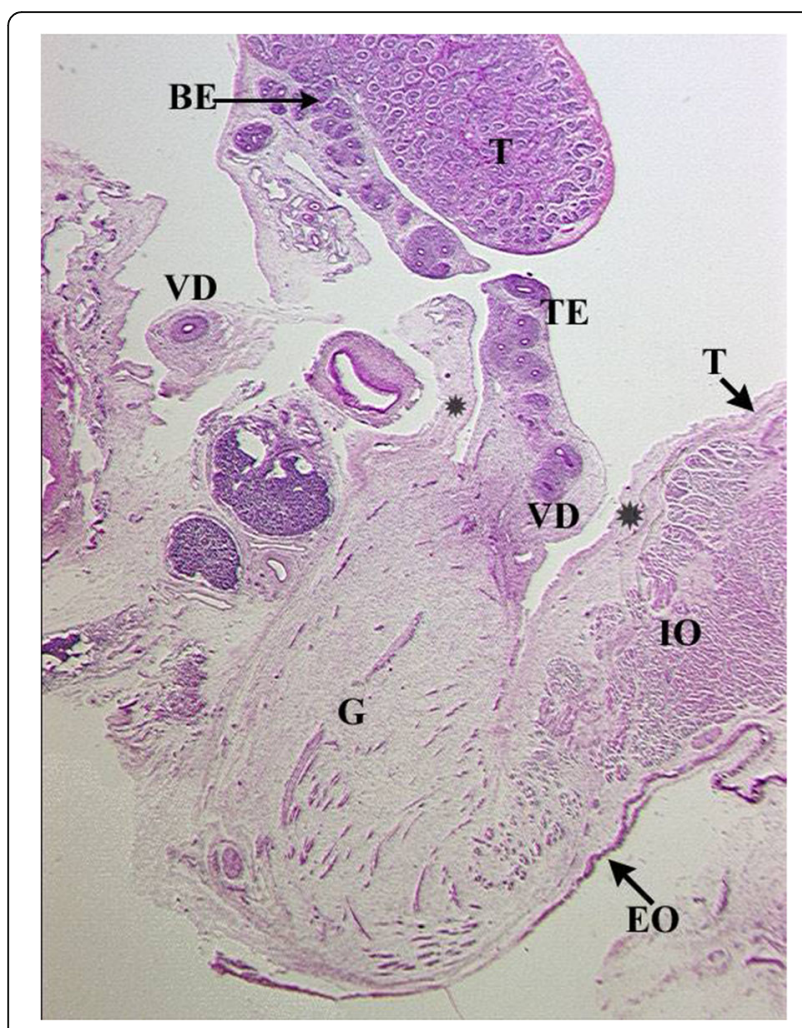

Fig. 4 Topography of epididymo-testicular unit presented in serial sagittal sections (from distal to proximal) of 6-month-old fetus. The gubernaculum $(G)$ is a thick cord composed of loose mesenchymal tissue with irregularly arrayed thin cremaster muscle fibers at periphery. At its proximal end, (AG) the gubernaculum is connected to the tail of the epididymis (TE, arrow). Short testicular ligament (TL) is connecting the tail of the epididymis to the testis (T). Notice; gubernaculum is never directly attached to the testis but always to the tail of the epididymis. [Deep inguinal ring and processus vaginalis (asterisk), transversus muscle fascia ( $T$, arrow), internal oblique muscle fascia $(\mathrm{IO})$, external oblique muscle fascia (EO), body of the epididymis $(\mathrm{BE})$, deferent duct (VD)]

\section{Androgens and FGFR1}

Androgens are the primary factors regulating epididymal development and function. However, a large body of evidence suggests that fibroblast growth factors also play important roles in the regulation and maintenance of the epididymis. In recent years, it has become clear that FGF signaling is involved in the development and normal functioning of male reproductive organs, such as the testis and epididymis [20]. For example, Fgf10 is expressed in the mesenchyme of the lower Wolffian ducts and regulates epithelial growth of the seminal vesicles and prostate [21]. In addition testosterone treatment increases "andromedins" Fgf10 transcription in the seminal vesicles [22] and at later stages of epididymal development; FGFR1 is specifically expressed in the undifferentiated mesenchyme [20, 23].

Moreover, FGFR1 mutations have been described in cases of idiopathic hypogonadotropic hypogonadism and

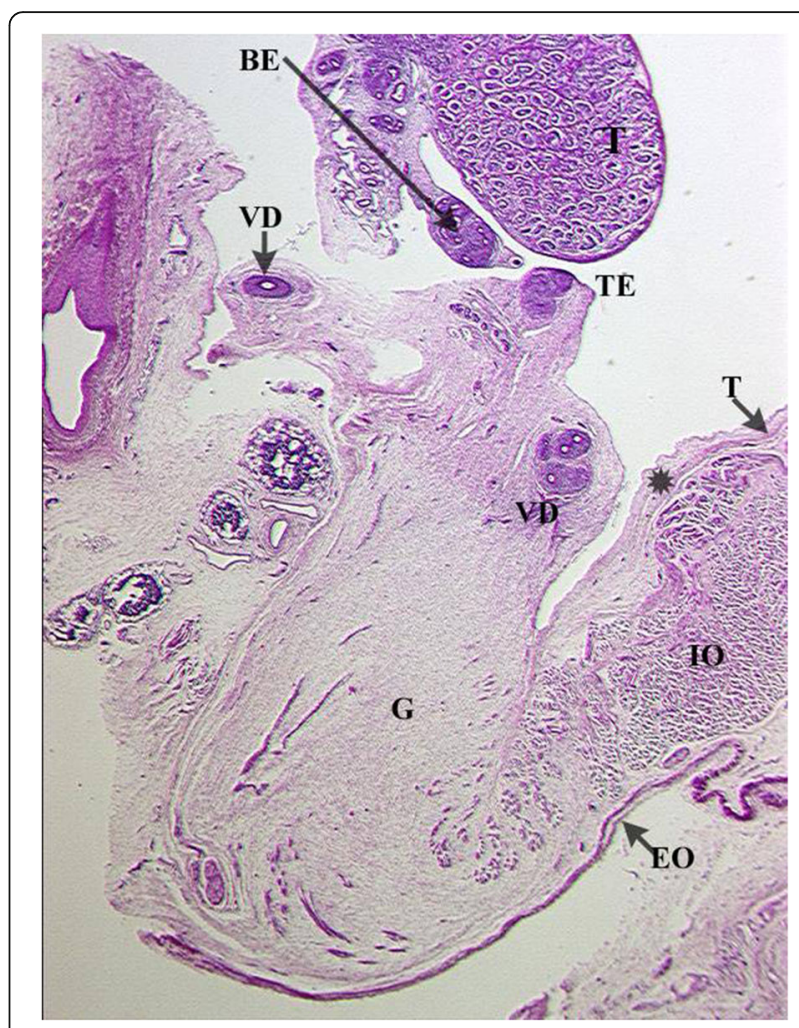

Fig. 5 Topography of epididymo-testicular unit presented in serial sagittal sections (from distal to proximal) of 6-month-old fetus. The gubernaculum $(\mathrm{G})$ is a thick cord composed of loose mesenchymal tissue with irregularly arrayed thin cremaster muscle fibers at periphery. At its proximal end, (AG) the gubernaculum is connected to the tail of the epididymis (TE, arrow). Short testicular ligament (TL) is connecting the tail of the epididymis to the testis $(T)$. Notice; gubernaculum is never directly attached to the testis but always to the tail of the epididymis. [Deep inguinal ring and processus vaginalis (asterisk), transversus muscle fascia (T, arrow), internal oblique muscle fascia ( $I O)$, external oblique muscle fascia (EO), body of the epididymis (BE), deferent duct (VD)]

cryptorchidism [24, 25]. In 2010, we reported impaired FGFR1 expression in the undescended testis but not in the descended gonad of unilateral cryptorchid boys [26]. Additionally, decreased FGFR1 protein levels have been found in cryptorchid epididymides of both humans and rodents [10]. These findings support the involvement of FGFR1 in regulating epididymal mesenchyme development [10]. It appears likely that the impaired FGFR1 protein secretion found in underdeveloped mesenchyme in cryptorchid humans and rodents contributes to defective epididymis formation and the subsequent undescended position. Based on our results, a subtle dysfunction (expression) of FGFR1, SOS1 and RAF1 is possibly involved in the development of unilateral or bilateral cryptorchidism. Many cases of syndromic cryptoepididymis, as well as a majority of isolated cases, have in common either a disturbance of FGFs, FGFR1, FGFR2, FGFR3, and/or a disturbance of the genes 


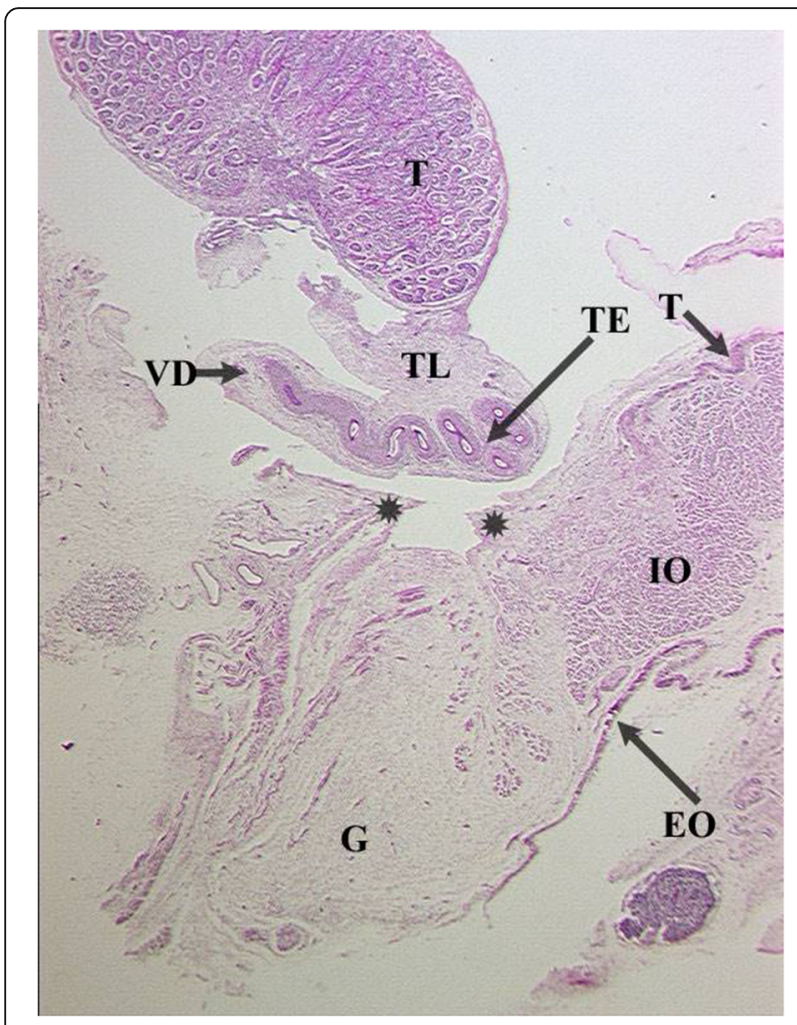

Fig. 6 Topography of epididymo-testicular unit presented in serial sagittal sections (from distal to proximal) of 6-month-old fetus. The gubernaculum $(G)$ is a thick cord composed of loose mesenchymal tissue with irregularly arrayed thin cremaster muscle fibers at periphery. At its proximal end, (AG) the gubernaculum is connected to the tail of the epididymis (TE, arrow). Short testicular ligament (TL) is connecting the tail of the epididymis to the testis (T). Notice; gubernaculum is never directly attached to the testis but always to the tail of the epididymis. [Deep inguinal ring and processus vaginalis (asterisk), transversus muscle fascia ( $T$, arrow), internal oblique muscle fascia $(\mathrm{IO})$, external oblique muscle fascia (EO), body of the epididymis $(\mathrm{BE})$, deferent duct (VD)]

involved in regulating the hypothalamic-pituitarygonadal axis [10]. Normally, muscle development requires signaling by members of the FGF family and their downstream effector early growth receptor 1 (EGR1) [27]. Deficient expression of EGR4 and EGR1 has been observed in cryptorchid boys [28]. Thus, the observed decrease in FGF expression may explain in decreased prokineteicin2 (PROK2) gene expression, inducing central hypogonadotropic hypogonadism and impaired epididymal mesoderm development, which results in abnormal descent of the epididymal-testicular union.

\section{Müllerian-inhibiting substance and INSL3}

In recent years, several genes have been found to be involved in the process of epididymo-testicular descent. Among the most frequently cited is INSL3. Insl3 mutant mice display bilateral or rear unilateral cryptorchidism $[29,30]$ and these mutants show a feminized

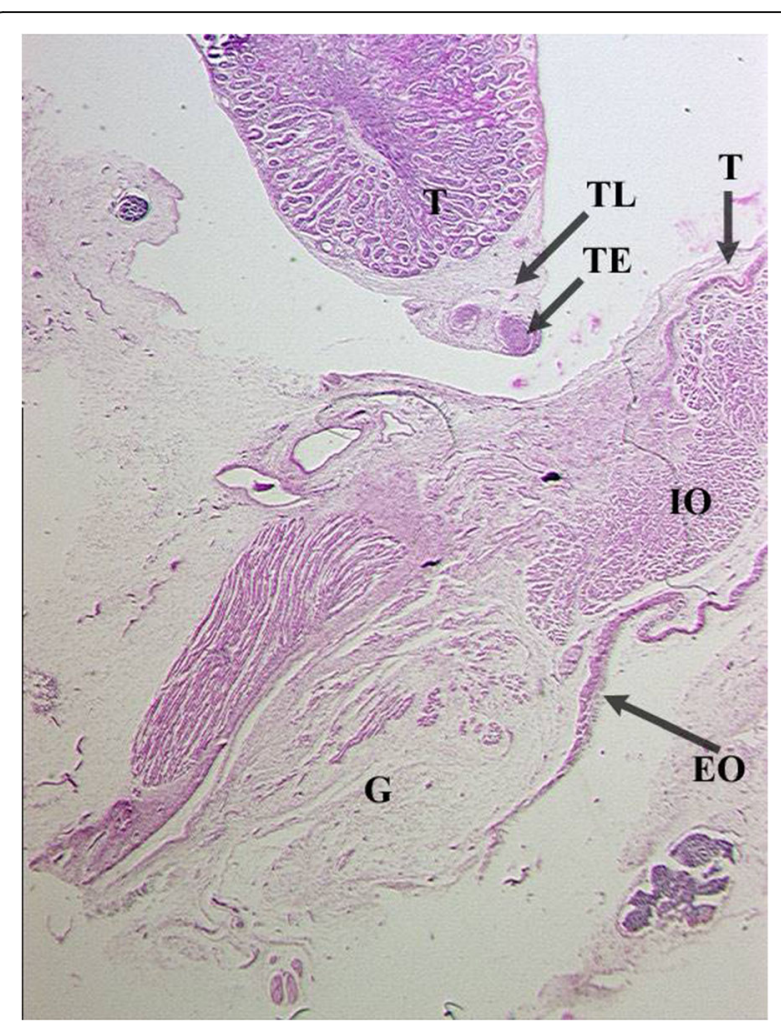

Fig. 7 Topography of epididymo-testicular unit presented in serial sagittal sections (from distal to proximal) of 6-month-old fetus. The gubernaculum $(G)$ is a thick cord composed of loose mesenchymal tissue with irregularly arrayed thin cremaster muscle fibers at periphery. At its proximal end, (AG) the gubernaculum is connected to the tail of the epididymis (TE, arrow). Short testicular ligament (TL) is connecting the tail of the epididymis to the testis (T). Notice; gubernaculum is never directly attached to the testis but always to the tail of the epididymis. [Deep inguinal ring and processus vaginalis (asterisk), transversus muscle fascia (T, arrow), internal oblique muscle fascia $(\mathrm{IO})$, external oblique muscle fascia (EO), body of the epididymis (BE), deferent duct (VD)]

gubernaculum (scrotal anlage) with a deficient mesenchymal core. Thus, Insl3 appears to have some role in the gubernacular (scrotal anlage) swelling reaction [31]. Furthermore, these mutants are claimed to have a normal epididymal development [30] which contrasts with our observation of arrested epididymal development [32]. Insl3 mutant mouse epididymis lacks smooth musculature because of defective $\alpha$-smooth muscle actin, which results in a high intraabdominal undescended position of the epididymo-testicular unit [32].

Of interest, Emmen et al. [33] reported that Insl3 is not essential for Wolffian duct growth, and that the Müllerian-inhibiting substance (AMH) does not influence gubernaculum growth. Moreover, mice with mutations in $\mathrm{AMH}$ and the $\mathrm{AMH}$ receptor, and mice with intrauterine immunization against MIS show normal epididymo-testicular descent and normal scrotum development [34-36]. Although MIS has no obvious effect on 


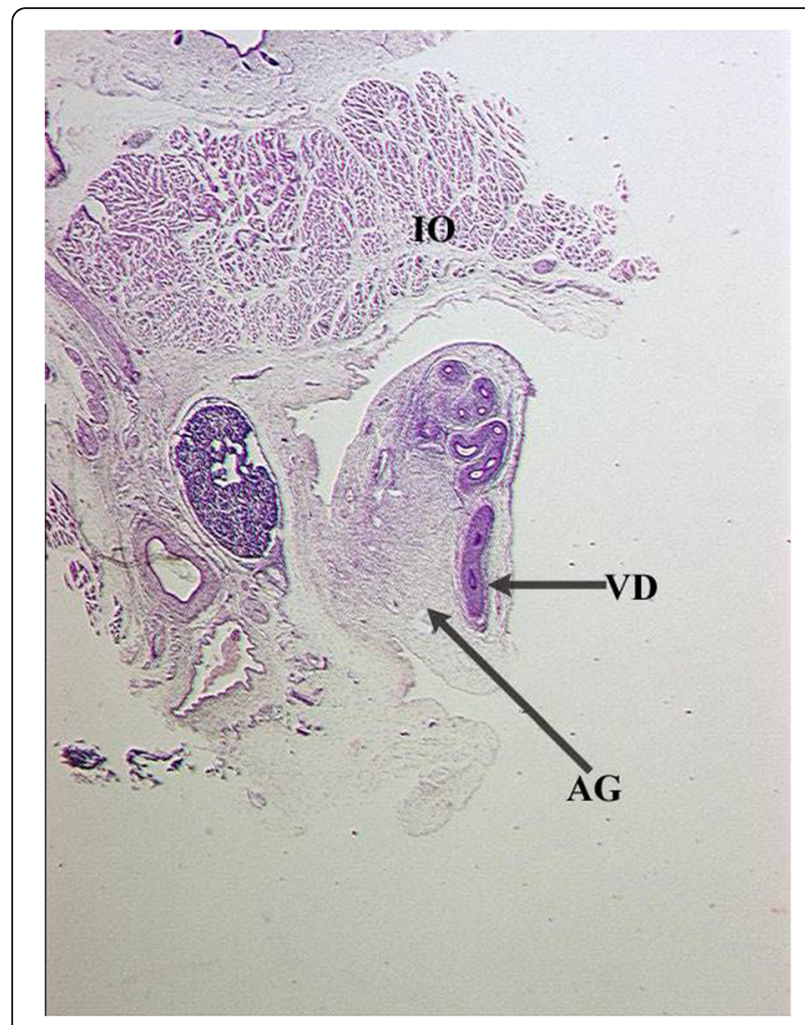

Fig. 8 Topography of epididymo-testicular unit presented in serial sagittal sections (from distal to proximal) of 6-month-old fetus. The gubernaculum $(G)$ is a thick cord composed of loose mesenchymal tissue with irregularly arrayed thin cremaster muscle fibers at periphery At its proximal end, (AG) the gubernaculum is connected to the tail of the epididymis (TE, arrow). Short testicular ligament (TL) is connecting the tail of the epididymis to the testis (T). Notice; gubernaculum is never directly attached to the testis but always to the tail of the epididymis. [Deep inguinal ring and processus vaginalis (asterisk), transversus muscle fascia ( $T$, arrow), internal oblique muscle fascia $(\mathrm{IO})$, external oblique muscle fascia (EO), body of the epididymis (BE), deferent duct (VD)]

epididymo-testicular descent in mice, it is still thought to affect human descent [37]. Hutson's group investigated boys with androgen insensitivity and found all testicles localized in the inguinal region, indicating that the 'first phase' of descent is androgenindependent and MIS-dependent [38]. In contrast, abdominal testes were found in $86 \%$ of patients showing a complete female phenotype, whereby decreasing incidence was associated with increasing masculinization [39]. Thus, in patients with complete androgen insensitivity, the testicular position correlates with the genital phenotype and degree of androgen insensitivity [39]. Furthermore, anti-Müllerian hormone (AMH), INSL3 and INHB hormone levels did not differ between cryptorchid and control boys [40]. Of importance, in persistent Müllerian duct syndrome abnormal androgen dependent epididymal development is a common phenomenon [41, 42].

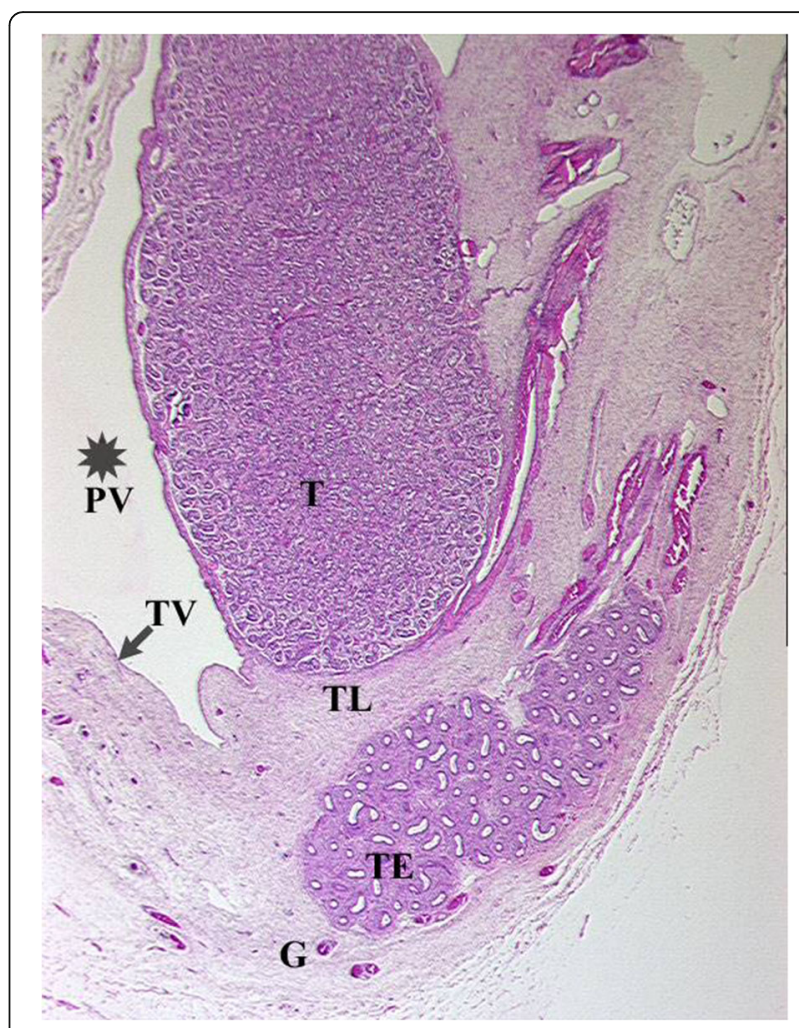

Fig. 924 weeks old fetus, sagittal sections displaying topographical relations between processus vaginalis, testis, epididymis, ligamentum testis and gubernaculum

\section{Cryptorchidism}

Cryptorchidism affects $1-3 \%$ of boys and is one of the most common endocrine diseases in childhood. The ultimate aim of all therapeutic approaches to cryptorchidism is to have both testes in the scrotum and to achieve a normal adult fertility potential.

\section{The etiology of cryptorchidism}

Epidemiologic studies have identified low birth weight as a factor very strongly associated with cryptorchidism, with additional evidence suggesting that maternal smoking and gestational diabetes further increase the risk $[1,43]$. Barthold et al. recently completed one of the largest published case-control studies of congenital and acquired surgically treated cases, and found that the association with cryptorchidism in first degree relatives was significant for both congenital (odds ratio [OR]: 6.1; 95\% CI: 2.0, 18.8) and acquired (OR: 8.7; $95 \%$ CI: $2.9,26.5)$ presentations, but reported no differences in parental transmission rates [1].

Our recent data are consistent with the hypothesis that hypogonadotropic hypogonadism in cryptorchid boys with altered mini-puberty is the consequence of a profoundly altered gene expression program involving protein-coding genes and long noncoding RNAs 


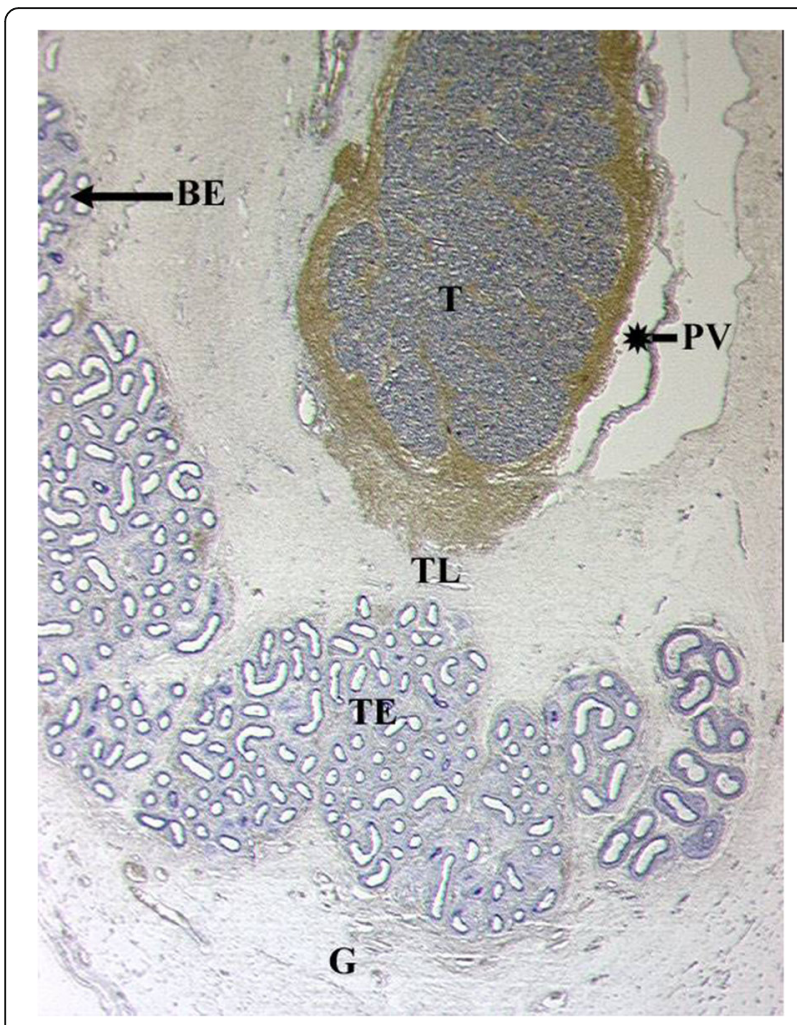

Fig. 10 Sagittal section of a newborn's body and the tail of epididymis and their topographical relation to processus vaginalis $\left({ }^{*}\right)$, testis $(T)$, ligamentum testis and gubernaculum. The gubernaculum is virtually inexistent $(G)$ and the testicular ligament (TL) undergoes the process of retroperitonealization and becomes a part of the scrotal wall. [Histological sections are personal material obtained from Töndery-Collection Institute of Anatomy Zürich]

(lncRNAs) [44]. We observed an increased abundance of long noncoding RNAs participating in epigenetic processes, including AIRN, FENDRR, XIST, and HOTAIR. Thus, the observed increase in familiar cryptorchidism may reflect an epigenetic phenomenon [44]. In our previous study we reported that the incidence of hypogonadotropic hypogonadism in isolated congenital undescended testes is as high as 70\%.

Evidence of a relative postpubertal gonadotropin deficiency became even clearer when LH plasma values were correlated with the presence of Ad spermatogonia [45]. In addition, in our long term prospective follow-up study, hormonal analyses confirmed previous observations of an inverse correlation between folliclestimulating hormone (FSH) levels and sperm count [45]. Gonadotropin levels, however, were more highly correlated with the presence or absence of Ad spermatogonia than with the number of undescended testes (Fig. 12) [45]. Thus, with their reliance on testicular position without support from histological findings, it is not surprising that Suomi et al. could not confirm hypogonadotropic hypogonadism in the cryptorchid boys in their population [46]. The patients with the greatest impairment of mini-puberty and who completely lacked gonocytes to Ad spermatogonia transformation were those with the most severe infertility. Consequently, the relative FSH and LH deficiencies observed in most of cryptorchid patients further support the hypothesis that hypogonadotropic hypogonadism is the main etiologic factor in cryptorchidism [45, 47-49].

The vast majority of data available support the conclusion that in many boys with undescended testes the response of Leydig cells to human chorionic gonadotropin (hCG) is diminished as compared to normal boys (for review, see [50]). Except for a blunted testosterone response to human chorionic gonadotropin, there is no evidence of altered steroidogenesis in cryptorchid testes prior to puberty [50]. Pretreatment of cryptorchid boys with hCG cancelled out the differences in their response to a stimulation test as compared to a control population [51]. Thus, the cause of the lower testosterone response seems to be at the pituitary or hypothalamic level, and may be a result of insufficient Leydig cell stimulation. Numerous LH-RH tests have demonstrated abnormally low LH response in cryptorchid boys [47-55]. Therefore, these results do not support the hypothesis that mild Leydig cell dysfunction resulting from the end organ dysgenesis is the etiologic factor for cryptorchidism, as postulated by Toppari et al. [56].

\section{A tale of two testes: The bilateral impact of a unilateral disease}

In 1987, Schindler et al. analyzing 495 testicular biopsies from cryptorchid boys and found that the scrotal testes in unilateral cryptorchidism showed germ cell loss in $30.1 \%$ [57]. In the remaining scrotal testes, the germ cell counts were in the low normal range with a significantly lower mean than that seen in scrotal testes associated with unilateral anorchia. Control biopsies were performed several months or years after orchidopexy in 18 boys with unilateral and in 24 boys with bilateral cryptorchidism. Orchidopexy did not improve the number of germ cells in either originally cryptorchid or in scrotal testes; the only postoperative change was an increase in tubular diameter [57]. Furthermore, Nistal et al. reported that the benefits of orchidopexy alone were very limited thus supporting the concept of congenital dysgenesis, not only of cryptorchid testis, but also of the contralateral gonad [58]. The fact that unilateral cryptorchid males develop azoospermia 25 times more often than the control population supports the concept that unilateral cryptorchidism is in fact a bilateral disease [59]. Finally, in boys with unilateral 


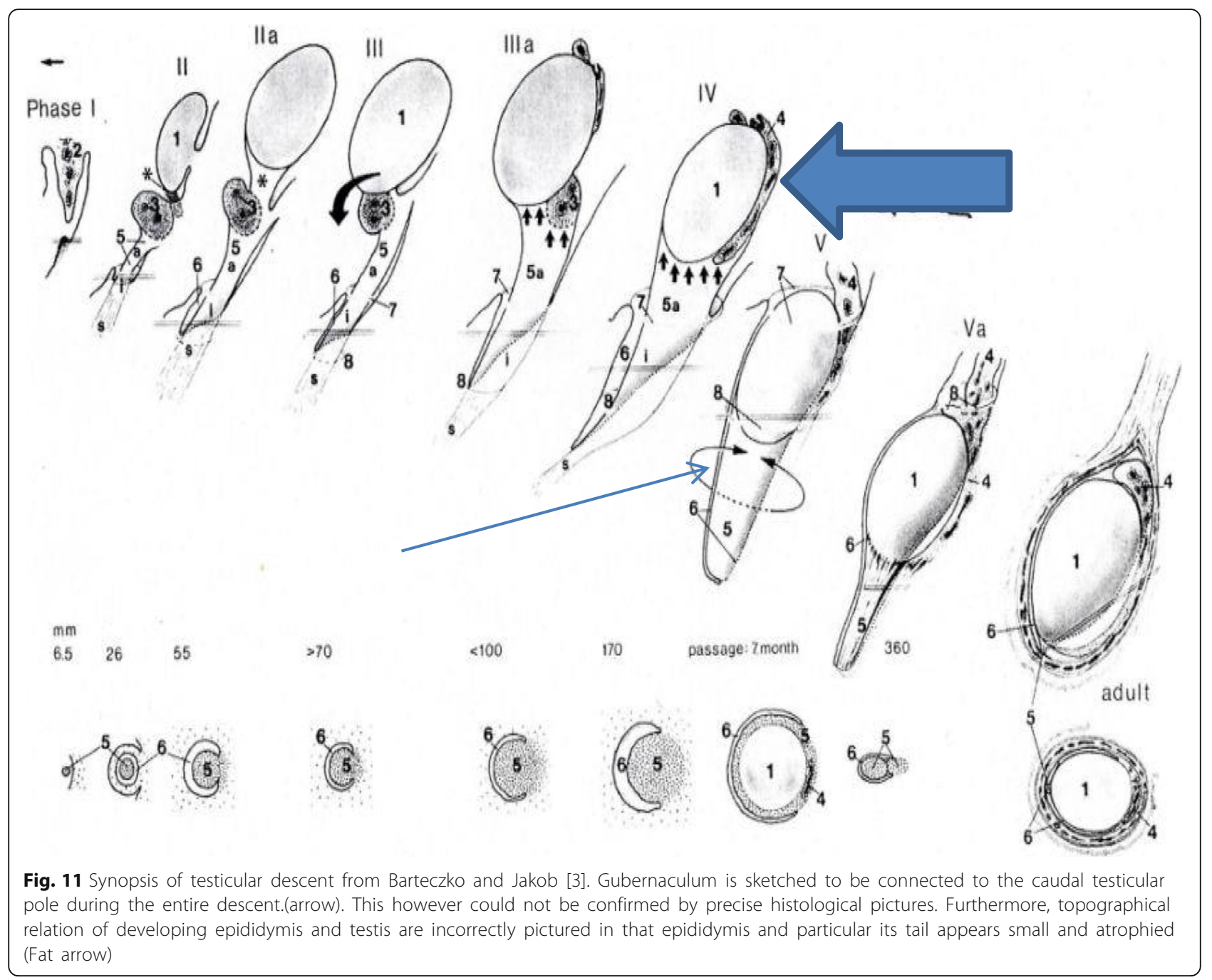

cryptorchidism, the testicular pathology caused by hormonal imbalance was bilateral; a total of $71 \%$ of scrotal testes had a reduced number of germ cells and $75 \%$ showed impaired gonocytes-to-Ad spermatogonia transformation [45].

When the incidence of paternity is analyzed, however, a distinct contrast to the above described histological findings becomes obvious. According to Lee et al., the percentage of unilateral cryptorchid men who achieve paternity does not differ from the unaffected population [60]. It should be noted that the study did not analyze testicular biopsies and depends solely on the fact that patients were orchidopexied and therefore considered to be cryptorchid [60]. However, the inevitable inclusions of low as well as intermediate and a high infertility risk patients and those misdiagnosed cases of retractile testes distorted the results. Therefore, the infertility outcome in cryptorchid boys should be assessed only after histological analysis of their testicular tissue, preferably of both testicles.

\section{Histology of cryptorchid testis}

It is generally believed that cryptorchidism represents heterogeneous group of disorders, which may explain controversies that persists about the long term consequences and treatment [1, 4]. From a histological point of view no such heterogeneity exists. The cryptorchid testis has a typical histology characterized by the depletion of germ cells resulting from impaired maturation of gonocytes accompanied by interstitial fibrosis, developmental arrest of Sertoli cells, and a diminished number of $\mathrm{Sf}$ (fetal) and $\mathrm{Sb}$ (polarized) Sertoli cells [61-67]. A hallmark of cryptorchid testis is a pronounced Leydig cell atrophy which also supports endocrinopathy as etiological factor in cryptorchidism [64, 67].

Thus, according to the histological picture the etiology of cryptorchidism is not in $80-90 \%$ of cases, unknown, as postulated by Virtanen and Toppari [68], but in contrast, $70 \%$ of cryptorchid testes show signs of hypogonadotropic hypogonadism with variable degree of impaired 


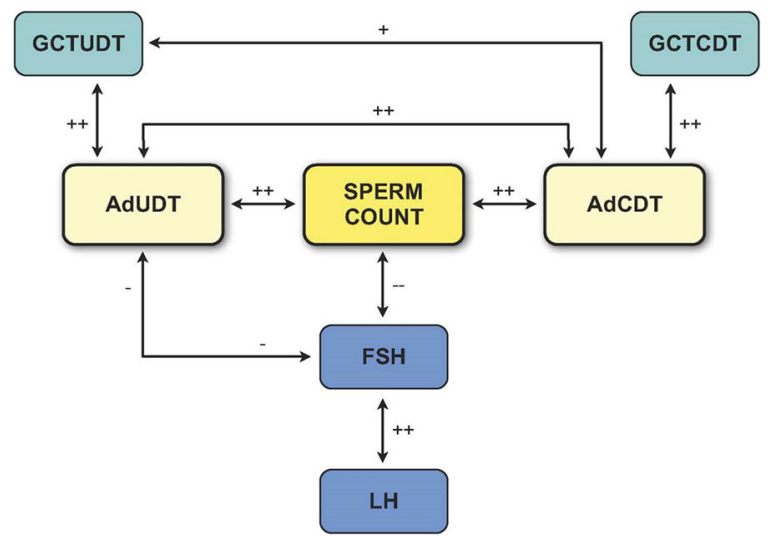

Fig. 12 Dominant role of Ad spermatogonia in predicting fertility outcome is outlined. + + / - -; strong correlation; +/- significant correlation. Ad CDT (scrotal testis) is the best predictor of future fertility. Ad UDT (undescended testis) is a decisive factor for supporting an FSH negative feedback mechanism. GCT UDT (total germ cell count in undescended testis) and GCT CDT (total germ cell count in scrotal testis) have no direct influence either on the sperm count or on the plasma FSH level

transition of gonocytes into Ad spermatogonia and distinct Leydig cell atrophy $[45,62,66]$.

\section{Mini-puberty and germ cells}

During mini-puberty, which occurs between 30 and 90 days of postnatal life in male infants, the substantial increase in $\mathrm{GnRH}$ secretion induces gonadotropin and testosterone production [69]. Testicular changes during the mini-puberty are further characterized by a small peak in testicular weight [70] and volume [71]. As a consequence, transformation of gonocytes into Ad spermatogonia takes place. Ad spermatogonia have a characteristic nuclear feature that distinguishes them from the other germ cells (e.g. fetal, transient, and Ap spermatogonia) [72]. Ad spermatogonia are flat, with a long oval nucleus, and are the only spermatogonia to have a region of rarefaction within the nucleus [72]. Adult dark (Ad) spermatogonia appear at three months of age and remain present in the testis for the rest of an individual's life [64, 72]. Therefore, the transformation of gonocytes into Ad spermatogonia, either directly or through intermediate stages, is not simply another step in a succession of developmental stages, but a major transformation. It represents the switch from a fetal reservoir of stem cells (gonocytes) to an adult reservoir of stem cells (Ad spermatogonia) from which all future germ cells are generated.

Based on results from our previous work we know that development of Ad spermatogonia is dependent on $\mathrm{LH}$ and testosterone [73]. Cryptorchid infants have an impaired testosterone increase during mini-puberty $[47,49$, 51, 74]. Furthermore, cryptorchid boys lacking Ad spermatogonia have low basal and stimulated gonadotropin plasma values that are compatible with those found in cases of hypogonadotropic hypogonadism [75]. If transformation during infancy of gonocytes into $\mathrm{Ad}$ spermatogonia fails, infertility is inevitable [45, 76]. Kim et al. analyzed the histology of testicular biopsies from patients with bilateral cryptorchidism and correlated it with post pubertal semen analysis, thereby confirming the prognostic importance of Ad spermatogonia for fertility [77].

\section{Mini-puberty and Sertoli cells}

Once spermatogenesis is established, the Sertoli cells hold the developing germ cells either in the spaces between adjacent pairs of cells, or in crypts in their luminal surface. Each Sertoli cell can sustain only a limited number of germ cells; therefore the number of Sertoli cells per testis determines the highest possible sperm production. The number of Sertoli cells in cryptorchid testes has been only sporadically studied [61, 78-80]. Cortes et al. $[78,79]$ found that a significant increase in the number of Sertoli cells occurs during the first three months of life. We reported, however, that during the first four months of life no difference could be found between the number of Sertoli cells in cryptorchid patients and patients with spontaneously descended testis $(22.38 \pm 1.01$ compared to $23.53 \pm 1.98)$ [81]. As age increases (5-12 months), this difference becomes more pronounced (23.20 \pm 1.41 , with cryptorchidism compared to $26.20 \pm 1.40$, in controls; $p=0.001$ ) [81]. Thus, the insufficient increase in the number of Sertoli cells is in accordance with recently observed significantly lower testosterone, AMH and inhibin B plasma values in cryptorchid boys [82]. Therefore, an early postnatal increase in inhibin $B$ is presumably due to the activation of the hypothalamic-pituitary testicular axis [83] and mirrors the proliferating activity of Sertoli cells. Of interest, the early postnatal rise of inhibin $\mathrm{B}$ is better correlated with LH and testosterone than with FSH $[84,85]$, raising the possibility that Sertoli cell proliferation in neonatal life depends more on LH/testosterone than on FSH [86].

\section{Current treatment options}

The greatest challenge in any clinical procedure for undescended testes is to exclude the retractile testis, for which no treatment is required except categorical reassurance. Inadequate examination has certainly fooled many doctors and even experienced surgeons many times [87]. More than half of the patients sent for treatment fall into this category [87]. If the retractile (but otherwise normal) testis is 'treated', the 'outcome' is obviously bound to be good. It is vital to exclude such cases from the procedures $[87,88]$. 


\section{Should surgery alone remain the best treatment recommended in guidelines?}

A recent equivocal summary of research on the physiology of testicular descent has resulted in a Nordic consensus article [89]. The Nordic consensus on the treatment of undescended testis relies greatly on observations reported by Ritzén et al. and Kollin et al. [90-92]. The key message was that the observed germ cell loss was caused solely by the age at the treatment. "Support" for early surgery was several years later given by Feyles et al. in their long-term fertility study [93]. Total sperm count in boys having orchidopexy before one year of age $(52.3 \pm 14.3$ million $/ \mathrm{mL}$ vs.30.4 \pm 23.5 million $/ \mathrm{mL}$ ) was not significantly different between two groups, while percentage of those with normal sperm count according to WHO standards was higher in male having had surgery before first year of life (96\% vs $75 \% ; p<0.042$ ) [93]. Of note, and this is important, the number of patients who developed azoospermia or severe oligospermia did not differ between patients who had surgery before and after the first year of age ( $p=0.39$, Fisher's Exact test) [94]. Indeed, in Feyles et al. study, severe infertility and azoospermia developed, irrespective of the age of treatment [94]. The key conclusions from Kollin et al. study are misleading for several reasons:

First, despite technical adequacy of histological tissue preparations, the responsible histologists clearly did not differentiate between gonocytes and spermatogonia in the germ cell population. This differentiation is important, because between nine months and three years in the normal testis, $40 \%$ of germ cells are lost due to the translation of gonocytes into spermatogonia, which is not induced by the cryptorchid position [6, 64, 94]. Thus, spermatogonia count and not the total cell count between two groups should be compared. Second, in the last 30 years, it has been convincingly shown that three-year-old, unilateral cryptorchid boys have an average germ cell count of 0.32 germ cells per tubular crosssection [64, 94, 95]. Of note, in this study, 3-year-old cryptorchid boys had an average germ cell count that was 320\% lower than expected. This suggested either selection bias or invalid histological analysis.

Third, the occurrence of Ad spermatogonia indicates completion of mini-puberty, and is an excellent parameter for predicting fertility outcome in cryptorchid boys [45]. Worth noting, only a comparison between groups of cryptorchid boys that lack Ad spermatogonia in both testes with a group of cryptorchid boys that have $\mathrm{Ad}$ spermatogonia in both testes could confirm previously reported observations that cryptorchid boys lacking Ad spermatogonia have hypogonadotropic hypogonadism, and should be treated with LH-RHa following successful and early orchidopexy, to escape infertility $[75,96]$. This comparison, despite adequate histological tissue preparation, was not performed by Kollin et al. [91]. Because of the inexperience of the histologist the analysis of testicular tissue was inadequate, which resulted in unsubstantiated and, misleading conclusions. Therefore, the postulated key message; that orchidopexy at 9 months is more beneficial for testicular development than an operation at $3 \mathrm{yr}$. of age, was based on incorrect histological data assessments.

Fourth, In contrast to the concerns raised by Nordic consensus group regarding harmful effect of hormonal treatment, the results of our study showed that hormonal treatment for undescended testis improved the histopathology of the contralateral testis without harming the germ cells [97, 98].

Finally, because testicular volume does not accurately predict germ cell count in patients with undescended testes, this parameter cannot be used to select patients for post-orchidopexy hormonal therapy. Therefore, testicular volume cannot replace the predictive value of testicular biopsy in the modern management of cryptorchidism and early surgery alone is an insufficient attempt to correct infertility development in at least 40 $50 \%$ of cryptorchid boys. Testicular biopsy is all the more justified because it allowed detection of in situ carcinoma in $0.6 \%$ of the cryptorchid boys that were studied.

Of interest, although the Nordic consensus group rejects hormonal treatment, recently one of the authors from this group recommended hormonal treatment for cryptorchidism in cases of bilateral cryptorchidism with hypogonadotropic hypogonadism [99].

\section{Forgotten history and ignored observations}

The main reason for not recommending hormonal treatment of the undescended epididymo-testicular union is supposedly that the success rate of this treatment is as low as $20 \%$ [90, 92]. This statement is misleading because it does not consider the distribution of the positions of the epididymo-testicular unit before treatment. Of importance, not performing three arm randomized placebo controlled studies could falsify success results because of the inclusion of retractile testes. Furthermore, in most of the studies the long follow-up period was short.

An approach other than a three-armed study was performed by Höcht in 1995. This study was randomized with LH-RH or surgery groups including 60 cryptorchid boys aged 2 to 9 years $[100,101]$. All patients randomized for the surgery treatment alone had histological changes compatible with cryptorchidism, so it is most likely that only undescended and not also retractile testes were treated. LH-RH treatment was successful in $59 \%$ of the patients. Ten years after the treatment 52\% of testes remained descended which is in sharp contrast to the $20 \%$ re-ascent claimed by Nordic consensus group 
[92]. Thus, LH-RH treatment is effective in achieving permanent descent of true cryptorchid testes [101]. The highest success was achieved when testes were localized pre-scrotal (Table 1).

Waldschmidt et al. described two independent long term follow-up studies of seven and five years after LH$\mathrm{RH}$ treatment, respectively. Seven years post-treatment $50.5 \%$ of the testes were in a scrotal position, while in the second study with a five year follow-up, $67 \%$ of the cryptorchid testes were in the scrotum [102]. Of importance, in a uniquely designed study, assigning the patients with cryptorchidism randomly into three-arm groups, GnRH treatment induced complete epididymo-testicular descent only in the treated group [17]. Furthermore, boys treated with buserelin had the highest number and the best maturation index of the germ cells [17].

In conclusion, hormonal pretreatment should remain the first therapeutic choice because it avoids resorting to surgery; In addition; it has no adverse effect on fertility and, in unsuccessful cases, facilitates orchidopexy and considerably helps reduce the incidence of postsurgical testicular atrophy.

\section{Combining classical physiological information and the output of cutting-edge genomics data into a complete picture \\ Temperature or transposon de-regulation}

It is widely accepted that exposure of the cryptorchid testis to abnormally high temperatures induces germ cell loss and infertility [103]. However, the temperature effect cannot explain testicular development of boys with deficiencies in 5-alpha reductase with bilateral cryptorchidism. These boys exhibit normal spermatogonia numbers and normal germ cell differentiation during the entire prepubertal period. Those findings are in sharp contrast to observations in boys with isolated bilateral cryptorchidism having identical testicular malpositioning [104]. Because the testicular positions in these two groups of boys are identical, their testes would be expected to have experienced the same temperature exposure. Therefore, if temperature was the only explanation for a massive germ cell loss in isolated bilateral cryptorchidism, the two groups should have exhibited

Table 1 Descent rate of epididymo-testicular unit from pre-scrotal position treated with $\mathrm{LH}-\mathrm{RH}$

\begin{tabular}{llll}
\hline Autor(s) & Year & $\mathrm{n}$ & \% success \\
\hline 1. De Muinck Keizer-Schrama et al. [116] & 1986 & $6 / 9$ & 66 \\
2. Borkenstein and Zobel [117] & 1987 & $5 / 9$ & 55 \\
3. Hagberg and Westphal [118] & 1987 & $8 / 17$ & 47 \\
4. Höcht [101] & 1987 & $3 / 4$ & 75 \\
5. Bica and Hadziselimovic [17, 119] & 1993 & $6 / 11$ & 54.5 \\
& & $28 / 50$ & 56 \\
\hline
\end{tabular}

identical germ cell loss. This, however, this was not the case [104]. Thus, at the level of spermatogonia, temperature appears to have only a negligible effect in contrast to the late germ cell developmental stages (adult testis).

The decreased germ cell count found in this group of boys could be the result of uncontrolled transposon activity inducing genomic instability and germ cell death. When we performed a genome-wide RNA profiling analysis, we found in our first study that genes important for transposon silencing were not expressed in the high infertility risk group of cryptorchid boys but only in the low infertility risk and control groups [105].

Intact mini-puberty appears to be essential for the development of the endogenous defense system mediated by transposon silencing $[105,106]$. Spermatogonia contain processing bodies that harbor P-element-induced wimpy testis (Piwi) proteins. Piwi proteins are associated specifically with Piwi-interacting RNAs to silence transposable DNA elements. Loss-of-function mutations in the Piwi pathway lead to de-repression of transposable elements, resulting in azoospermia and infertility [106]. Furthermore, deletion of gametocyte-specific factor 1 (GTSF1), a protein involved in Piwi-mediated transcriptional repression, causes male-specific sterility and derepression of LINE-1 (L1) retrotransposons. Seven members of the Tudor gene family, and three members of the DEAD-box RNA helicase family were found in our second study to show significantly lower RNA signals in the high-infertility-risk group. In the immune-histochemical analysis, patients from the low-infertility-risk group showed coherently stronger staining for GTSF1 and PIWIL4 proteins and weaker staining for the L1 transposon when compared to the high-infertility-risk samples. These findings provide the first evidence consistent with the idea that infertility in cryptorchidism is a consequence of alterations in the Piwi pathway and the derepression of transposon induced by the impaired testosterone function during mini-puberty [106].

\section{Idiopathic central hypogonadotropic hypogonadism}

Recent observation of lower plasma LH levels in cryptorchid boys with the most pronounced testicular pathology and impaired gonocytes transformation [94], confirms previous findings that this group of cryptorchid boys suffers hypogonadotropic hypogonadism [75]. The estimated incidence of defective mini-puberty in boys with cryptorchidism could be as high as $70 \%[45,107]$. Using whole genome RNA profiling of testicular biopsies by DNA strand-specific RNA sequencing we found multiple differences in gene expression between the high and low infertility risk groups, confirming the importance of an intact hypothalamus-pituitary testicular axis for fertility development. [28, 44, 108, 109] Furthermore, 
we observed decreased PROK2, CHD7, FGFR1, and $S P R Y 4$ expression in the high infertility risk group of cryptorchid boys [104]. In particular, EGR4 and PITX1, which are involved in regulating the secretion of luteinizing hormone, were virtually not expressed [108].

Our RNA profiling data strongly support the theory that in the high infertility risk group of cryptorchid boys insufficient PROK2/CHD7/FGFR1/SPRY4 gene expression, together with observed deficient EGR4 and PITX1 signaling, induce deficient $\mathrm{LH}$ secretion, which results in impaired mini-puberty $[28,44,105,108,109]$. Of interest is that in bilateral cryptorchid infants with hypogonadotropic hypogonadism having Kallmann-, Charge syndrome or panhypopituitarism, displaying undetectable LH and testosterone plasma level. Daily subcutaneous injections of the recombinant LH $75+$ FSH 150 IU for a period of three months rescued mini-puberty repairing micropenis and cryptorchidism (all testes descended). [110] The treatment also induced high-normal activation of Leydig and Sertoli cells as well as normal LH, FSH, INHB, AMH and testosterone levels [110]. Identical hormonal results and $75 \%$ successfully descended testes were achieved in bilateral cryptorchid boys with congenital hypogonadotropic hypogonadism using subcutaneous LH and FSH infusions [111].

\section{GnRH treatment to rescue fertility}

In a substantial number of cryptorchid males, early and apparently successful orchidopexy does not improve fertility, because it does not cure the underlying pathophysiological cause, which is the impaired transformation of gonocytes into Ad spermatogonia [28, 45]. It is important to realize that more than half of the patients presenting with unilateral cryptorchidism, and the majority of those presenting with bilateral cryptorchidism, have an abnormal semen analysis, which indicates that unilateral cryptorchidism is in fact a bilateral disease and therefore a serious andrological problem [59]. Despite timely and successful surgery, $32 \%$ of patients with bilateral and $10 \%$ with unilateral cryptorchidism will develop azoospermia [59].

Thus, cryptorchidism represents the most common cause of non-obstructive azoospermia in men. GnRH therapy is a worthwhile solution for this andrological problem. Initial results of GnRHa treatment on alternate days over a period of six months showed that this treatment did not inhibit gonadotropin secretion, while LH levels increased and atrophic juvenile Leydig cells regenerated toward the end of the treatment [112]. Thus, the treatment increased the number of germ and Leydig cells [97, 112]. Cryptorchid boys of a median age of eight years, who were treated with a gonadotropin-releasing hormone agonist, showed after puberty improved sperm concentrations when compared to an untreated control group [113]. Worth noting, long term follow-up in high infertility risk group of cryptorchid boys treated before the age of six showed normal sperm concentrations in $86 \%$ of cases [114]. This results strongly contrasts with those of the 'surgery only' group in which not a single patient had a normal semen analysis and 20\% suffered from azoospermia [114].

Finally, a recent prospective randomized study designed for boys with isolated bilateral cryptorchidism without Ad spermatogonia in the testicular biopsy were randomly divided into two groups. One group underwent the second orchidopexy without any hormonal treatment and the second group received intranasal $\mathrm{LH}$ RHa therapy for six months followed by a second orchidopexy. In contrast to the boys treated with surgery alone, all patients from the LH-RHa treated group completed the transition of gonocytes into Ad spermatogonia $(p=0.008)$. Thus, treatment with LH-RH agonist (buserelin) is beneficial and should be considered in an attempt to correct impaired mini-puberty to improve the fertility potential in cryptorchid boys [115]. At the molecular level, GnRH induces a significant transcriptional response, including protein coding genes involved in pituitary development, the hypothalamic-pituitarygonadal axis, and testosterone synthesis. Expression patterns of prepubertal germ cells indicate that genes involved in meiosis and post meiotic germ cell development are already up-regulated before puberty $[28,108]$. The observed differential gene expression profiles of gonocytes and spermatogonia markers, especially DMRTC2, PAX7, T (Brachyury) and TERT, highlight their importance for the development of Ad spermatogonia with specific functions in self-renewal and differentiation [109]. Furthermore, we could show that in $\mathrm{GnRH}$ treated high infertility risk patients, the development of Ad spermatogonia is rescued through the activation of alternative genes. We suggest that $\mathrm{GnRH}$ -induced elevated testosterone and LH levels reconstitute self-renewal properties of the Ad spermatogonial stem cells and help prepare them for commitment to differentiation, by inducing retinoic acid responsive genes such as NRG1, NRG3 and PAX7 [109]. Together with our earlier observations on the level of the hypothalamic-pituitary-gonadal-axis of differentially expressed genes in high infertility risk patients we suggest that EGR4 and PITX1 controlled by PROK2/CHD7/ FGFR1/SPRY4 gene expression is responsible for $\mathrm{LH}$ deficiency, which in turn affects germ cell transitional effectors FGFR3, FGF9, NANOS2, NANOS3, SOHLH1 and SOHLH2. Upon GnRHa treatment, however, alternative pathways are activated including the $\mathrm{LH}$-secretion orchestrating factors EGR2, EGR3, TAC1, TAC3, PROP1 and $L E P$, and the gonocytes-to-Ad spermatogonia transition effectors DMRTC2, T, PAX7, TERT, NRG1, NRG3, RBMY1B, RBMY1E and RBMY1J [109] (Table 2). 
Table 2 Pathophysiology of cryptorchidism induced infertility. Treatment with GnRH permanently stimulates alternative pathway to induce transition of gonocytes and undifferentiated spermatogonia into Ad spermatogonia

\begin{tabular}{lll}
\hline FGFR1 & FGFR1 $\downarrow$ & FGFR1 $\downarrow$ \\
$\downarrow$ & $\downarrow$ & $\downarrow$ \\
PROK2 & PROK2 $\downarrow$ & PROK2 $\downarrow$ \\
$\downarrow$ & $\downarrow$ & $\mid \leftarrow$ GnRH \\
GnRH & GnRH $\downarrow$ & EGR2 / EGR3 $\uparrow$ \\
$\downarrow$ & $\downarrow$ & $\downarrow$ \\
EGR4 / PITX1 & EGR4 /PITX1 $\downarrow$ & LH $\uparrow$ \\
$\downarrow$ & $\mid$ & $\downarrow$ \\
LH & LH $\downarrow$ & HSD17 B2 $\uparrow$ \\
$\downarrow$ & $\mid$ & CYP19A1 $\uparrow$ \\
Testosterone & Testosterone $\downarrow$ & Testosterone $\uparrow$ \\
$\downarrow$ & $\downarrow$ & $\downarrow$ \\
T-brachyury,POU2F2 & T-brachyury $\downarrow$ & POU2F2 $\uparrow T$-brachyury $\uparrow$ \\
$\downarrow$ & $\downarrow$ & $\downarrow$ \\
Ad & No Ad & Ad \\
$\downarrow$ & $\downarrow$ & $\downarrow$ \\
Fertility & Infertility & Fertility \\
\hline
\end{tabular}

\section{Conclusion}

Five main conclusions are possible based on the available evidence to date. First, hypogonadotropic hypogonadism is the most common cause of cryptorchidism. Molecular observations support a crucial role for PROK2 in the pathophysiology of cryptorchidism with impaired PROK2/CHD7/FGFR1/SPRY4 gene expression inducing $\mathrm{LH}$ deficiency as controlled by the regulators EGR4 and PITX1. Second, unilateral cryptorchidism is a bilateral disease and a serious andrological problem. Third, hormonal treatment successfully induces epididymo-testicular descent (Table 3). Fourth, the most severe associated infertility is seen in men with a history of cryptorchidism who had the greatest impairments in mini-puberty

Table 3 Basel concept of cryptorchidism treatment

\begin{tabular}{|c|c|}
\hline 1. & $\begin{array}{l}\text { LH-RH } 1.2 \text { mg/ day for } 28 \text { days; } \\
\text { If no or partial success: }\end{array}$ \\
\hline 2. & $\begin{array}{l}500 \text { IU hCG / week for } 3 \text { weeks; } \\
\text { If no descent: }\end{array}$ \\
\hline 3. & $\begin{array}{l}\text { Orchidopexy and bilateral biopsy; } \\
\text { If no bilateral Ad spermatogonia: }\end{array}$ \\
\hline 4. & LH-RH $10 \mu \mathrm{g}$ on alternate day for six months. \\
\hline
\end{tabular}

and completely lacked gonocytes translation into Ad spermatogonia in both testes (Table 3). Finally, when patients at increased risk of infertility (those lacking Ad spermatogonia) received treatment with $\mathrm{GnRH}$, normal semen concentration analyses were observed in $86 \%$ of cases. Omitting GnRH treatment, one third of men with a history of defective mini-puberty will develop azoospermia despite successful surgery.

\begin{abstract}
Abbreviations
AIRN: Antisense of IGF2R Non-Protein Coding RNA; AMH: Anti- Müllerian hormone; CHD7: Chromodomain Helicase DNA Binding Protein 7; CYP19A1: Cytochrome P450 Family 19 Subfamily A Member1; DMRTC2: DMRT Like Family C2; EGR1: Early growth response 1; EGR3: Early growth response 3; EGR4: Early growth response 4; FENDRR: FOXF1 Adjacent Non-Coding Developmental Regulatory RNA; FGF: Fibroblast growth factor; FGFR1: Fibroblast growth factor receptor 1; FSH: Follicle-stimulating hormone; GnRH: Gonadotropin-releasing hormone; GnRHa: Gonadotropinreleasing hormone agonist; GTSF1: Gametocyte-specific factor 1; hCG: Human chorionic gonadotropin; HOTAIR: HOX Transcript Antisense RNA; HSD17B2: Hydroxysteroid 17-Beta Dehydrogenase 2; INSL3: Insulin-like factor3; IU: International unit; LEP: Leptin; LH: Luteinizing hormone; LHRH: Luteinizing hormone-releasing hormone; LH-RHa: Luteinizing hormonereleasing hormone analogue; IncRNAs: Long noncoding RNAs; NANOS2: Nanos C2HC-Type Zinc Finger 2; NRG1: Neuregulin 1; OR: Odds ratio; PAX7: Paired Box 7; PITX1: Paired like homeodomain 1; PIWI 1: Pelement-induced wimpy; Piwi Like RNA-Mediated Gene Silencing 1; POU2F2: POU Class 2 Homeobox 2; PROK2: prokineticin 2; PROP1: PROP Paired-Like Homeobox 1; RAF1: Raf-1 Proto-oncogene, serine/threonine kinase; RBMY1B: RNA Binding Motif Protein, Y-Linked, Family 1, Member B; Sb: Polarized sertoli cells; Sf: Fetal sertoli cells; SOHLH1: Spermatogenesis and oogenesis specific basic helix-loop-helix 1; SOS1: SOS Ras/Rac guanine nucleotide exchange factor 1; SPRY4: Sprouty RTK signaling antagonist 4; T: T Brachyury transcription factor; TAC1: Tachykinin precursor 1; TERT: Telomerase reverse transcriptase; WHO: World Health Organization; XIST: X inactive specific transcript (Non-Protein Coding)
\end{abstract}

Funding

No funding was received for the present work.

\section{Availability of data and materials}

The datasets used and/or analyzed during the current study are available from the corresponding author on reasonable request.

\section{Competing interests}

I declare that I have no financial or non-financial competing interests.

\section{Publisher's Note}

Springer Nature remains neutral with regard to jurisdictional claims in published maps and institutional affiliations.

Received: 19 September 2017 Accepted: 27 October 2017

Published online: 14 November 2017

\section{References}

1. Barthold JS, Reinhardt S, Thorup J. Genetic, maternal, and environmental risk factors for cryptorchidism: an update. Eur J Pediatr Surg. 2016;26:399-408.

2. Hutson JMA. Biphasic model for the hormonal control of testicular descent. Lancet. 1985;2:419-21.

3. Barteczko KJ, Jacob MI. The testicular descent in human. Origin, development and fate of the gubernaculum Hunteri, processus vaginalis peritonei and gonadal ligaments. Adv Anat Embryol Cell Biol. 2000;156:1-98.

4. Hutson JM. Testicular descent. In: Hutson JM, Thorup JM, Spencer WB, editors. Descent of the testis. 2nd ed. Switzerland: springer international publishing; 2016. p. 17-44.

5. Bergh A, Helander HF, Wahlqvist L. Studies on factors governing testicular descent in the rat-particularly the role of gubernaculum testis. Int J Androl. 1978;1:342-56. 
6. Hadziselimovic F. Embryology of testicular descent and maldescent. In: Hadziselimovic F, Kogan S, Cromie W, Hinman F, editors. Cryptorchidism management and implications. Springer: Berlin; 1983. p. 11-53.

7. Hinton BT, Galdamez MM, Sutherland A, Bomgardner D, Xu B, Abdel-Fattah $R$, Yang $L$. How do you get six meters of epididymis inside a human scrotum? J Androl. 2011;32:558-64.

8. Hadziselimovic F. Mechanism of testicular descent. Urol Res. 1984;12:155-7.

9. Mollaeian M, Mehrabi V, Elahi B. Significance of epididymal and ductal anomalies associated with undescended testis: study in 652 cases. Urology. 1994;43:857-60.

10. Hadziselimovic F. Involvement of fibroblast growth factors and their receptors in epididymo-testicular descent and maldescent. Mol Syndromol. 2015:6:261-7.

11. Rochester JR, Chung WC, Hayes TB, Tsai PS. Opposite sex housing reactivates the declining $\mathrm{GnRH}$ system in aged transgenic male mice with FGF signaling deficiency. Am J Physiol Endocrinol Metab. 2008;303:1428-39.

12. Chung WC, Moyle SS, Tsai PS. Fibroblast growth factor 8 signaling through fibroblast growth factor receptor 1 is required for the emergence of gonadotropin-releasing hormone neurons. Endocrinology. 2008;149:49975003.

13. Itoh N, Ohta H, Konishi M. Endocrine FGFs: evolution, physiology, pathophysiology, and pharmacotherapy. Front Endocrinol (Lausanne). 2015; 29(6):154. https://doi.org/10.3389/fendo2015.00154.

14. Radovick S, Wray S, Lee E, Nicols DK, Nakayama Y, Weintraub BD, et al. Migratory arrest of gonadotropin-releasing hormone neurons in transgenic mice. Proc Natl Acad Sci U S A. 1991;88:3402-6.

15. Charlton HM, Halpin DM, Iddon C, Rosie R, Levy G, McDowell IF, et al. The effects of daily administration of single and multiple injections of gonadotropin-releasing hormone on pituitary and gonadal function in the hypogonadal (hpg) mouse. Endocrinology. 1983;113:535-44.

16. Pask AJ, Kanasaki H, Kaiser UB, Conn PM, Janovick JA, Stockton DW, et al A novel mouse model of hypogonadotropic hypogonadism: N-ethyl-Nnitrosourea-induced gonadotropin-releasing hormone receptor gene mutation. Mol Endocrinol. 2005;19:972-81.

17. Bica DT, Hadziselimovic F. The behavior of epididymis, processus vaginalis, and testicular descent in cryptorchid boys treated with buserelin. Eur Pediatr. 1993;152(Suppl 2):38-42.

18. Yuan FP, Lin DX, Rao CV, Lei ZM. Cryptorchidism in LhrKO animals and the effect of testosterone-replacement therapy. Hum Reprod. 2006;21:936-42.

19. Hadziselimovic F. Pathogenesis of cryptorchidism. In: Kogan SJ, Hafez ESE, editors. Pediatric Andrology. The Hague: Martinus Nijhoff; 1981. p. 147-62.

20. Cotton LM, O'Bryan MK, Hinton BT. Cellular signaling by fibroblast growth factors (FGFs) and their receptors (FGFRs) in male reproduction. Endocr Rev. 2008;29:193-216.

21. Archambeault DR, Tomaszewski J, Joseph A, Hinton BT, Yao HH. Epithelialmesenchymal crosstalk in Wolffian duct and fetal testis cord development. Genesis. 2009:47:40-8.

22. Thomson AA, Cunha GR. Prostatic growth and development are regulated by FGF10. Development. 1999;126:3693-701.

23. Basilico C, Moscatelli D. The FGF family of growth factors and oncogenes. Adv Cancer. Res. 1992:59:115-65.

24. Dodé C, Levilliers J, Dupont JM, De Paepe A, Le Dû N, Soussi-Yanicostas N et al. Loss-of-function mutations in FGFR1 cause autosomal dominant Kallmann syndrome. Nat Genet. 2003;33:463-5.

25. Pitteloud N, Quinton R, Pearce S, Raivio T, Acierno J, Dwyer A, et al. Digenic mutations account for variable phenotypes in idiopathic hypogonadotropic hypogonadism. J Clin Invest. 2007;117:457-63.

26. Hadziselimovic NO, de Geyter C, Demougin P, Oakeley EJ, Hadziselimovic F. Decreased expression of FGFR1, SOS1, RAF1 genes in cryptorchidism. Urol Int. 2010;84:353-61.

27. Nentwich O, Dingwell KS, Nordheim A, Smith JC. Downstream of FGF during mesoderm formation in Xenopus: the roles of Elk-1 and Egr-1. Dev Biol. 2009;336:313-26.

28. Hadziselimovic F, Hadziselimovic NO, Demougin P, Krey G, Hoecht B, Oakeley EJ. EGR4 is a master gene responsible for fertility in cryptorchidism. Sex Dev. 2009:3:253-63.

29. Zimmermann S, Steding G, Emmen JM, Brinkmann AO, Nayernia K, Holstein AF, et al. Targeted disruption of the Insl3 gene causes bilateral cryptorchidism. Mol Endocrinol. 1999;13:681-91.

30. Nef S, Parada LF. Cryptorchidism in mice mutant for Insl3. Nat Genet. 1999; 22:295-9.
31. Kubota Y, Nef S, Farmer PJ, Temelcos C, Parada LF, Hutson JM. Leydig insulin-like hormone, gubernacular development and testicular descent. J Urol. 2001;165:1673-5.

32. Hadziselimovic F, Adham I. Insulin 3-like hormone and its role in epididymo-testicular de-scent. Int Braz J Urol. 2007;33:407-11.

33. Emmen JM, McLuskey A, Adham IM, Engel W, Grootegoed JA, Brinkmann AO. Hormonal control of gubernaculum development during testis descent: gubernaculum outgrowth in vitro requires both insulin-like factor and androgen. Endocrinology. 2000;141:4720-7.

34. Picard JY, Tran D, Vigier B, Josso N. Persistence of Müllerian ducts in male rabbits by passive immunization against anti-Müllerian hormone during fetal life. C R Seances Acad Sci III. 1983;297:567-70.

35. Behringer RR, Finegold MJ, Cate RL. Müllerian inhibiting substances function during mammalian sexual development. Cell. 1994;79:415-25.

36. Bartlett JE, Lee SM, Mishina Y, Behringer RR, Yang N, Wolf J, et al. Gubernacular development in Müllerian inhibiting substance receptordeficient mice. BJU Int. 2002;1:113-8.

37. Hutson JM, Lopez-Marambio FA. The possible role of $\mathrm{AMH}$ in shortening the gubernacular cord in testicular descent: a reappraisal of the evidence. J Pediatr Surg. 2017; https://doi.org/10.1016/jjpedsurg201705.021.

38. Clarnette TD, Sugita $Y$, Hutson JM. Genital anomalies in human and animal models reveal the mechanisms and hormones governing testicular descent. Br J Urol. 1997;79:99112.

39. Barthold JS, Kumasi-Rivers K, Upadhyay J, Shekarriz B, Imperato-Mcginley J. Testicular position in the androgen insensitivity syndrome: implications for the role of androgens in testicular descent. J Urol. 2000;164:497-501.

40. Komarowska MD, Milewski R, Charkiewicz R, Matuszczak E, Sulewska A, Zelazowska-Rutkowska B, et al. Are anti-Müllerian hormone and its receptor polymorphism associated with the hormonal condition of undescended testes? Adv Med Sci. 2016:61:288-92.

41. Picard JY, Cate RL, Racine C, Josso N. The persistent Müllerian duct syndrome: an update based upon a personal experience of 157 cases. Sex Dev. 2017:11:109-25.

42. Josso N, di Clemente N, Gouédard L. Anti-Müllerian hormone and its receptors. Mol Cell Endocrinol. 2001;179:25-32.

43. Hakonsen LB, Ernst A, Ramlau-Hansen CH. Maternal cigarette smoking during pregnancy and reproductive health in children: a review of epidemiological studies. Asian J Andol. 2014;16:39-49.

44. Hadziselimovic F, Gegenschatz-Schmid K, Verkauskas G, Demougin P, Bilius $V$, Dasevicius D, Stadler MB. GnRHa treatment of cryptorchid boys affects genes involved in hormonal control of the HPG axis and fertility. Sex Dev. 2017;11:126-36

45. Hadziselimovic F, Hoecht B. Testicular histology related to fertility outcome and postpubertal hormone status in cryptorchidism. Klinische Padiatrie. 2008;220:302-7

46. Suomi AM, Main KM, Kaleva M, Schmidt IM, Chellakooty M, Virtanen HE, et al. Hormonal changes in 3-month-old cryptorchid boys. J Clin Endocrinol Metab. 2006:91:953-8.

47. Baker BA, Morley R, Lucas A. Plasma testosterone in preterm infants with cryptorchidism. Arch Dis Child. 1988:63:1198-200.

48. Job JC, Toublanc JE, Chaussain JL, Gendrel D, Roger M, Canlorbe P. The pituitary-gonadal axis in cryptorchid infants and children. Eur J Pediatr. 1987; 146(Suppl 2):2-5

49. Hamza AF, Elrahim M, Elnagar O, Maaty SA, Bassiouny E, Jehannin B. Testicular descent: when to interfere? Eur J Pediatr Surg. 2001;11:173-6.

50. Jockenhovel F, Swerdloff RS. Alterations in stereoidogenic capacity of Leydig cells in cryptorchid testis. In: Abney TO, Keel BA, editors. The Cryptorchid testis. Boca Raton: CRS Press Inc; 1989. p. 36-48.

51. Gendrel D, Roger M, Chaussain JL, Canlorbe P, Job JC. Correlation of pituitary and testicular responses to stimulation tests in cryptorchid children. Acta Endocrinol. 1977:86:641-50.

52. Gendrel D, Job JC, Chaussain JL, Roger M, Garnier P, Canlorbe P. The pituitary-gonadal responses to stimulation tests in cryptorchid children. In: Job JC, editor. Cryptorchidism -diagnosis and treatment. Basel: Karger; Pediatr Adolesc Endocrinol; 1979. p. 121-8.

53. Jacobelli A, Agostino A, Vecci E, Simeoni A, Ferrantelli M. Studies on the pituitary-testicular axis in boys with cryptorchidism. In: Bierich JR, Giarola A, editors. Cryptorchidism. London: Academic Press; 1979. p. 261-9.

54. Mazzi C, Riva LP, Morandi G, Mainini E, Scarsi G, Salaroli AA. Study of cryptorchid subjects. Evaluation of the hypophyseal-testicular axis in the prepubertal period. In: Bierich JR, Giarola A, editors. Cryptorchidism. London: Academic Press; 1979. p. 269-78. 
55. Bollerslev J, Rohl H, Krag Sorensen E, Bennet P. Gonadotropin and androgen levels in patients operated upon for cryptorchidism. Dan Med Bull. 1986;33: 336-8.

56. Toppari J, Kaleva M, Virtanen HE, Main KM, Skakkebaek NE. Luteinizing hormone in testicular descent. Mol Cell Endocrinol. 2007;269:34-7.

57. Schindler AM, Diaz P, Cuendet A, Sizonenko PC. Cryptorchidism: a morphological study of 670 biopsies. Helv Paediatr Acta. 1987;42:145-58.

58. Nistal M, Paniagua R, Riestra ML, Reyes-Múgica M, Cajaiba MM. Bilateral prepubertal testicular biopsies predict significance of cryptorchidismassociated mixed testicular atrophy, and allow assessment of fertility. Am J Surg Pathol. 2007;31:1269-76.

59. Hadziselimovic F, Hadziselimovic NO, Demougin P, Oakeley EJ. Testicular gene expression in cryptorchid boys at risk of azoospermia. Sex Dev. 2011;5: 49-59.

60. Lee PA, O'Leary LA, Songer NJ, Coughlin MT, Bellinger MF, LaPorte RE Paternity after unilateral cryptorchidism. Pediatrics. 1996;98:676-9.

61. Hadziselimovic F, Seguchi H. Ultramikroskopische Untersuchungen an Tubulus Seminiferous bei Kindern von der Geburt bis zur Pubertät. II. Entwicklung und Morphologie der Sertolizellen. Verh Anat Ges. 1974;68: 149-61.

62. Hadziselimovic F, Herzog B, Seguchi H. Surgical correction of cryptorchidism at 2 years: electron microscopic and morphometric investigations. J Pediatr Surg. 1975;10:19-26.

63. Nistal M, Abaurrea MA, Paniagua R. Morphological and histometric study on the human Sertoli cell from birth to the onset of puberty. J Anat. 1982;134 351-64.

64. Hadziselimovic F. Cryptorchidism Adv Anat Embryol Cell Biol 1977;53/3.

65. Hadziselimovic F, Herzog B. Hodenerkrankungen im Kindesalter. Stuttgart: Georg Thieme Verlag; 1990. p. 13-107.

66. Huff DS, Fenig DM, Canning DA, Carr MG, Zderic SA, Snyder HM 3rd. Abnormal germ cell development in cryptorchidism. Horm Res. 2001;55:11-7.

67. Hadziselimović $F$, Seguchi $H$. Electron microscopic study of the undescended testicles of children. Acta Anat (Basel). 1973;86:474-83.

68. Virtanen HE, Toppari J. Epidemiology and pathogenesis of cryptorchidism. Int J Androl. 2008;14:49-58.

69. Forest MG, Sizonenko PC, Cathland AM, Bertrand J. Hypophyso-gonada function in humans during the first year of life. J Clin Invest. 1974;53:819-28.

70. Siebert JR. Testicular weight in infancy (letter). J Pediatr. 1982;100:835-6.

71. Cassorla FG, Golden SM, Johsonbaugh RE, Hermon WM, Loriaux DL, Sherins RJ. Testicular volume during early infancy. J Pediatr. 1981;99:742-3.

72. Seguchi A, Hadziselimovic F. Ultramikroskopische Untersuchungen am Tubulus seminiferous bei Kindern von der Geburt bis zur Pubertat. I. Spermatogonienentwicklung. Verh Anat Ges. 1974;68:133-48.

73. Zivkovic D, Bica DT, Hadziselimovic F. Relationship between adult dark spermatogonia and secretory capacity of Leydig cells in cryptorchidism. BJU Int. 2007;100:1147-9.

74. Raivio T, Toppari J, Kaleva M, Virtanen H, Haavisto AM, Dunkel L, Jänne OA. Serum androgen bioactivity in cryptorchid and noncryptorchid boys during the postnatal reproductive hormone surge. J Clin Endocrinol Metab. 2003; 88:2597-9.

75. Hadziselimovic F, Herzog B, Girard J. Lack of germ cells and endocrinology in cryptorchid boys from one to six years of life. In: Biereich JR, Giarola A, editors. Cryptorchidism. London: Academic Press; 1979. p. 129-34.

76. Hadziselimovic F, Herzog B. The importance of both an early orchidopexy and germ cell maturation for fertility. Lancet. 2001;358:1156-7.

77. Kim SS, Kolon T, Casale P, Carr M, Zderic SA, Canning DA, et al. The positive predictive value of prepubertal testis biopsy on adult sperm density in patients with bilateral undescended testes. J Urol. 2008;179:144-5.

78. Nistal M, Paniagua R, Diez-Pardo JA. Histological classification of undescended testes. Hum Pathol. 1980;11:666-73.

79. Cortes D, Müller J, Skaekkebaek E. Proliferation of Sertoli cells during development of the human testis assessed by stereological methods. Int J Androl. 1987;10:589-96.

80. Cortes D. Cryptorchidism - aspects of pathogenesis, histology and treatment. Scand J Urol Nephrol Suppl. 1998;196:1-54.

81. Zivkovic D, Hadziselimovic F. Development of the Sertoli cells during minipuberty in normal and cryptorchid testes. Urol Int. 2009;82:71-82.

82. Hamdi SM, Almont T, Galinier P, Mieusset R, Thonneau P. Altered secretion of Sertoli cells hormones in 2 year old prepubertal cryptorchid boys: a cross-sectional study. Andrology. 2017:5(4):783-9. https://doi.org/10.1111/ andr.12373.
83. Andersson AM, Toppari J, Haavisto AM, Petersen JH, Simell T, Simell O, Skakkebaek NE. Longitudinal reproductive hormone profiles in infants: peak of inhibin B levels in infant boys exceeds levels in adult men. J Clin Endocrinol Metab. 1998;83:675-81.

84. Bergada I, Rojas G, Ropelato G, Ayuso S, Bergada C, Campo S. Sexual dimorphism in circulating monomeric and dimeric inhibins in normal boys and girls from birth to puberty. Clin Endocrinol. 1999;51:455-60.

85. Borgato S, Giacchero R, Morpurgo P, Persani L, Beck-Peccoz P. Physiological secretion of gonadotropins and inhibin B during the first year of postnatal life in both sexes. 5th European Congress of Endocrinology, Turin, Italy, 2001, Abstract 0-079.

86. Meachem,SJ, Nieschlag E, Simoni M. Inhibin B In male reproduction: pathophysiology and clinical relevance. Eur J Endocrinol 2001;145:561-571.

87. Leading article. Treatment of undescended testis. Lancet. 1957;273:989-90.

88. Hadziselimovic F. Fertility and cryptorchidism. Am J Dis Child. 1985;139:963-4.

89. Kutasy B, Thorup JM, Wester T. Comments to recent guidelines on undescended testis. Eur J Pediatr Surg. 2016;26:432-5.

90. Ritzén EM, Bergh A, Bjerknes R, Christiansen P, Cortes D, Haugen SE, et al. Nordic consensus on treatment of undescended testes. Acta Paediatr. 2007; 96:638-43.

91. Kollin C, Stukenborg JB, Nurmio M, Sundqvist E. GustafsonT, Söder O, et al. boys with undescended testes: endocrine, volumetric and morphometric studies on testicular function before and after orchidopexy at nine months or three years of age. J Clin Endocrinol Metab. 2012;97:4588-95.

92. Ritzén EM. Undescended testes: a consensus on management. Eur J Endocrinol. 2008;159:87-90.

93. Feyles F, Peiretti V, Mussa A, Manenti M, Canavese F, Cortese MG, Lala R. Improved sperm count and motility in young men surgically treated for cryptorchidism in the first year of life. Eur J Pediatr Surg. 2014;24:376-80.

94. Verkauskas G, Malcius D, Eidukaite A, Dasevisius D, Vilimas J, Bilius V, Hadziselimovic F. Prospective study of histological and endocrine parameters of gonadal function in boys with cryptorchidism. J Pediatr Urol. 2016;12:238.e1-6. https://doi.org/10.1016/j.jpurol.2016.05.007.

95. Hadziselimović F. Pathogenesis and treatment of undescended testes. Eur J Pediatr. 1982;139:255-65.

96. Hedinger C. Diagnostic and prognostic value of testis biopsy. Schweiz Med Wochenschr. 1971;101:1084-9.

97. Hadziselimovic F, Huff D, Duckett J, Herzog B, Elder J, Snyder H, Buser M. Treatment of cryptorchidism with low doses of Buserelin over a 6-months period. Eur J Pediatr. 1987;146:S56-8.

98. Zivkovic D, Bica DG, Hadziselimovic F. Effects of hormonal treatment on the contralateral descended testis in unilateral cryptorchidism. J Pediatr Urol. 2006:2:468-72

99. Cortes D, Holt R, de Knegt VE. Hormonal aspects of the pathogenesis and treatment of cryptorchidism. Eur J Pediatr Surg. 2016;26:409-17.

100. Höcht B. Therapy of prepubertal cryptorchidism. Clinical experiences with LH-RH treatment. Fortschr Med. 1983:101:1531-5.

101. Höcht B. LH-RH treatment for cryptorchidism. Randomized study and 10year follow-up results. Eur J Pediatr. 1987;146(Suppl 2):44-6.

102. Waldschmidt J, Doede T, Vygen I. The results of 9 years of experience with a combined treatment with LH-RH and HCG for cryptorchidism. Eur J Pediatr. 1993;152(Suppl 2):34-6.

103. Setchell BP. The parkers lecture. Heat and the testis. J Reprod Fertil. 1998; 114:179-94

104. Hadziselimovic F, Dessouky N. Differences in testicular development between 5 alpha-reductase 2 deficiency and isolated bilateral cryptorchidism. J Urol. 2008;180:1116-20.

105. Hadziselimovic F, Hadziselimovic NO, Demougin P, Krey G, Oakeley EJ. Deficient expression of genes involved in the endogenous defense system against transposons in cryptorchid boys with impaired mini-puberty. Sex Dev. 2011;5:287-93.

106. Hadziselimovic F, Hadziselimovic NO, Demougin P, Krey G, Oakeley E. Piwipathway alteration induces LINE-1 transposon de-repression and infertility development in cryptorchidism. Sex Dev. 2015;9:98-104.

107. Bilius V, Verkauskas G, Dasevicius D, Kazlauskas V, Malcius D, Hadziselimovic F. Incidence of high infertility risk among unilateral cryptorchid boys. Urol Int. 2015;95:142-5

108. Hadziselimovic F, Gegenschatz-Schmid K, Verkauskas G, Docampo-Garcia MJ Demougin P, Bilius V, et al. Gene expression changes underlying idiopathic central hypogonadism in cryptorchidism with defective mini-puberty. Sex Dev. 2016;10:136-46. 
109. Gegenschatz-Schmid K, Verkauskas G, Demougin P, Bilius V, Dasevicius D, Stadler M Hadziselimovic F. DMRTC2, PAX7, T and TERT are implicated in male germ cell development following curative GnRH treatment for cryptorchidism induced infertility. Genes. 2017;8:267. https://doi.org/10.3390/ genes8100267.

110. Papadimitriou DT, Chrysis D, Zoupanos G, Nyktari G, Liakou E, Papadimitriou A. Replacement of Male Mini-Puberty. ESPE Abstracts. 2016;86 FC3.2.

111. Lambert AS, Bougneres P. Growth and descent of the testes in infants with hypogonadotropic hypogonadism receiving subcutaneous gonadotropin infusion. Int J Pediatr Endocrinol. 2016;2016:13.

112. Hadziselimovic F, Hoecht B, Herzog B, Girard J. Does long term treatment with Buserelin improve the fertility chances of cryptorchid testes? In: Labrie F, Belanger A, Dupont A, editors. LH-RH and its analogues. Amsterdam: Elsevier; 1984. p. 488-503.

113. Hadziselimovic F, Herzog B. Treatment with a luteinizing hormone-releasing hormone analogue after successful orchidopexy markedly improves the chance of fertility later in life. J Urol. 1997;158:1193-5.

114. Hadziselimovic F. Successful treatment of unilateral cryptorchid boys risking infertility with LH-RH analogue. Int Braz J Urol. 2008;34:319-26.

115. B.Vincel, Verkauskas G, Bilius V, Dasevicius D, Malcius D, Jones B, Hadziselimovic F. LH-RHa treatment correct defective mini-puberty in cryptorchid boys; prospective randomized study. EUPSA 2017. Dent Abstr.

116. De Muinck Keizer-Schrama SM, Hazebroek FW, Matroos AW, Drop SL, Molenaar JC, Visser HK. Double-blind, placebo-controlled study of luteinizing-hormone-releasing-hormone nasal spray in treatment of undescended testes. Lancet 1986;1:876-880.

117. Borkenstein M, Zobel V. Treatment of cryptorchism with LHRH nasal spray. Wien Klin Wochenschr. 1985;97:414-6.

118. Hagberg S, Westphal O. Results of combined hormonal and surgical treatment for undescended testis in boys under 3 years of age. A randomized study. Eur J Pediatr. 1987;146(Suppl 2):38-9.

119. Bica DT, Hadziselimovic F. Buserelin treatment of cryptorchidism: a randomized, double-blind, placebo-controlled study. J Urol. 1992;148:617-21.

\section{Submit your next manuscript to BioMed Central and we will help you at every step:}

- We accept pre-submission inquiries

- Our selector tool helps you to find the most relevant journal

- We provide round the clock customer support

- Convenient online submission

- Thorough peer review

- Inclusion in PubMed and all major indexing services

- Maximum visibility for your research

Submit your manuscript at www.biomedcentral.com/submit 